A Research Report

for Rockwell Hanford Operations

\title{
Evaluation of Silver Mordenite for Radioiodine Retention at the Purex Process Facility Modification
}
R. D. Scheele
L. L. Burger

July 1987

Prepared for the U.S. Department of Energy under Contract DE-AC06-76RLO 1830

Pacific Northwest Laboratory Operated for the U.S. Department of Energy by Battelle Memorial Institute 


\title{
DISCLAIMER
}

This report was prepared as an account of work sponsored by an agency of the United States Government. Neither the United States Government nor any agency thereof, nor Battelle Memorial Institute, nor any of their employees, makes any warranty, expressed or implied, or assumes any legal liability or responsibility for the accuracy, completeness, or usefulness of any information, apparatus, product, or process disclosed, or represents that its use would not infringe privately owned rights. Reference herein to any specific commercial product, process, or service by trade name, trademark, manufacturer, or otherwise, does not necessarily constitute or imply its endorsement, recommendation, or favoring by the United States Government of any agency thereof, or Battelle Memorial Institute. The views and opinions of authors expressed herein do not necessarly state or reflect those of the United States Government or any agency thereof, or Battelle Memorial Institute.

\author{
PACIFIC NORTHWEST LABORATORY \\ operated by \\ BATTELLE MEMORIAL INSTITUTE \\ for the \\ UNITED STATES DEPARTMENT OF ENERGY \\ under Contract DE-AC06-76RLO 1830
}

\begin{tabular}{c} 
Printed in the United States of America \\
Available from \\
National Technical Information Service \\
United States Department of Commerce \\
5285 Port Royal Road \\
Springfield, Virginia 22161 \\
NTIS Price Codes \\
Microfiche A01 \\
Printed Copy \\
\multicolumn{3}{|c}{} \\
Pages \\
$001-025$ \\
$026-050$ \\
$051-075$
\end{tabular}


EVALUATION OF SILVER MORDENITE FOR RADIOIODINE RETENTION AT THE PUREX PROCESS FACILITY MODIFICATION

\author{
R. D. Scheele \\ L. L. Burger
}

July 1987

Prepared for

the U.S. Department of Energy under Contract DE-AC06-76RLO 1830

Pacific Northwest Laboratory

Richland, Washington 99352 


\section{SUMMARY}

In 1985 and 1986 the Pacific Northwest Laboratory (PNL) evaluated the efficiency of silver zeolite, in particular silver mordenite (AgZ), as a trapping agent for radioiodine from the PUREX ${ }^{(a)}$ Process Facility Modification's (PFM) nuclear fuel dissolver off gas. The PFM is a new headend treatment plant being designed by Rockwell Hanford Operations for the PUREX Plant at the Hanford Site. The tests were performed to determine AgZ performance at normal, off-normal, and standby conditions. Normal conditions were defined as 1 vol\% nitric oxide (NO), 1 vol\% nitrogen dioxide $\left(\mathrm{NO}_{2}\right)$, and an $\mathrm{AgZ}$ temperature of $150^{\circ} \mathrm{C}$. Off-normal conditions, which could occur if the $\mathrm{NO}_{x}$ removal system failed or was placed downstream of the iodine removal system, would cause increases in the $\mathrm{NO}$ and $\mathrm{NO}_{2}$ concentrations to 9 vol\% each, and in the bed temperature to $230^{\circ} \mathrm{C}$. Standby conditions would occur when the fuel dissolver was not operating; the off-gas system would continue to operate with air flow even though there would be no iodine or $\mathrm{NO}_{\mathrm{x}}$ in the inlet air.

To determine the efficiency of AgZ under these various conditions, a series of experiments was designed to investigate the effect of NO concentration in the range 1 to 9 vol\%, of $\mathrm{NO}_{2}$ concentration in the range 1 to 9 vol\%, and of bed temperature in the range 150 to $230^{\circ} \mathrm{C}$, and to allow statistical analysis of the results. In addition, several special tests were performed to examine the effects of input iodine concentration, AgZ bed length, operation at standby conditions for extended periods, and the efficiency of reduced silver mordenite, $\mathrm{Ag}^{\circ} \mathrm{Z}$.

With some qualifications, this experimental study showed that AgZ is an effective method for removing iodine from the PFM dissolver off gas at both normal and off-normal conditions. Bed loading and exit concentrations were independent of input concentration in the range 0.35 to $10.5 \mu \mathrm{mol} \mathrm{CH} \mathrm{CH}_{3} \mathrm{I} / \mathrm{L}$; however, bed loading was somewhat dependent on temperature. A $12-\mathrm{cm}$ bed was routinely capable of reducing the effluent iodine concentration from

\footnotetext{
(a) Plutonium and Uranium Recovery by EXtraction. The facility is located at the Hanford Site in southeastern Washington state, and is operated for the U.S. Department of Energy by Rockwell Hanford Operations.
} 
$10 \mu \mathrm{mol} \mathrm{I} / \mathrm{L}$ to a nominal $10^{-4} \mu \mathrm{mol} \mathrm{I} / \mathrm{L}$. However, this low value is greater than the target $10^{-5} \mu \mathrm{mol} \mathrm{I} / \mathrm{L}$ set for the PFM. Some tests indicated that longer beds $(16-\mathrm{cm})$ may be capable of reducing the effluent concentration to the target level. A disturbing aspect of these results, however, is that not all of the trapped iodine is firmly fixed on the AgZ. Some iodine will migrate when exposed to iodine-free air at standby conditions and could result in premature breakthrough.

The statistical analysis of the results of the parametric study to determine the effect of normal and off-normal operating conditions on the iodine loading of the AgZ at breakthrough showed that a higher loading of iodine on $\mathrm{AgZ}$ can be achieved at $150^{\circ} \mathrm{C}$ than at $230^{\circ} \mathrm{C}$. Increasing the temperature from 150 to $230^{\circ} \mathrm{C}$ caused an average $10 \%$ decrease in the loading at breakthrough from 0.43 to $0.39 \mathrm{mmol} \mathrm{I} / \mathrm{g} \mathrm{AgZ}$ for a $12-\mathrm{cm}$ bed. The NO and $\mathrm{NO}_{2}$ concentration levels in the range of 1 to 9 vol\% had no detectable effects. The results of this set of experiments indicate that operation of the iodine control system at normal or off-normal conditions will not greatly impact the final loading at breakthrough.

The special test to determine the effect of the input iodine concentration showed that the influent $\mathrm{CH}_{3} \mathrm{I}$ concentration in the range of 0.35 to $10.5 \mu \mathrm{mol} \mathrm{I} / \mathrm{L}$ did not affect the effluent concentration during normal loading and standby operations before breakthrough. The results from this special test were compared with those of the run from the parametric study performed at normal conditions, and the results indicated also that the loading was unaffected by the change in input concentration.

The tests to determine the impact of increasing bed length produced several interesting results. The first is that a longer bed will improve the loading capacity of the AgZ at breakthrough. Secondly, a longer bed may reduce the effluent concentration to less than $10^{-4} \mu \mathrm{mol} \mathrm{I} / \mathrm{L}$, possibly to the target level, during loading and standby conditions. The effluent concentrations for these tests during loading trended downward with increasing bed length. Thirdly another test suggests that over an extended period of time with an iodine input of $\geq 10^{-4} \mu \mathrm{mol} \mathrm{I} / \mathrm{L}$, the effluent concentration will be $10^{-4} \mu \mathrm{mol} \mathrm{I} / \mathrm{L}$. In that test, the standby effluent from a $16-\mathrm{cm}$ bed loaded to 
$0.4 \mathrm{mmol} \mathrm{I} / \mathrm{g} \mathrm{AgZ}$ was fed into a second $16-\mathrm{cm}$ bed. After 20 days with the effluent concentration from the first bed at $10^{-4} \mu \mathrm{mol} \mathrm{I} / \mathrm{L}$, the effluent from the second $\mathrm{AgZ}$ bed was also $10^{-4} \mu \mathrm{mol} \mathrm{I} / \mathrm{L}$.

In all of the extended tests at standby conditions, the effluent concentration from a loaded bed increased to well above the target level. This increase indicates that a portion of the iodine is not initially bound firmly to the AgZ. In one of the extended standby tests, the chronic release decreased, after peaking, to $10^{-5} \mu \mathrm{mol} \mathrm{I} / \mathrm{L}$. In another test, the release decreased to $10^{-4} \mu \mathrm{mol} \mathrm{I} / \mathrm{L}$, suggesting that extended treatment at standby conditions or just at temperature would result in a stable iodine loading witl an effluent concentration at the target level. If a stable loading does exist, achieving it may be a function of time and temperature.

The special test using $\mathrm{Ag}^{\mathrm{O}} \mathrm{Z}$ indicated that the achievable loading at breakthrough is about $30 \%$ less for $\mathrm{Ag}^{\circ} \mathrm{Z}$ than $\mathrm{AgZ}$. This finding was unexpected, based on past work which showed that a higher loading was obtained with $\mathrm{Ag}^{\circ} \mathrm{Z}$. This test suggested that the trapped iodine loaded onto an $\mathrm{Ag}^{\circ} \mathrm{Z}$ bed at normal conditions is more tightly bound than iodine trapped on an $\mathrm{AgZ}$ bed. Before application of $\mathrm{Ag}^{\mathrm{O} Z}$ to the PFM, further studies would be required.

This experimental program showed that even though AgZ was effective as an iodine trap at all potential conditions in the PFM, its performance did not meet all of the target criteria.

In addition to the iodine trapping studies, we measured several physical properties of the AgZ. Air-equilibrated $-10+16$ mesh AgZ had a density of $0.993 \mathrm{~g} / \mathrm{mL}$ (10 wt\% water) and a free volume of $40 \%$. The pressure drop increased rapidly with a decrease in mesh size. The pressure drop for a $1.25-\mathrm{cm}$-diameter bed at $22^{\circ} \mathrm{C}$ ranged from 90 to $2210 \mathrm{~mm} \mathrm{H} \mathrm{H}_{2} \mathrm{O} / \mathrm{m}$ of bed length at a face velocity of $4.9 \mathrm{~m} / \mathrm{min}$ for mesh sizes ranging from $-10+16$ to $-40+70$ mesh AgZ. Temperature also affected the pressure drop across the bed. Increasing the temperature from 22 to $100^{\circ} \mathrm{C}$ increased the pressure drop by 40 to $50 \%$, and a change from 100 to $200^{\circ} \mathrm{C}$ caused an increase of $30 \%$. 
Additional studies of alternative materials and/or studies to understand and improve the chemistry and reactions rates of the trapping process may be required to meet the target control levels established by Rockwell for the PFM. 


\section{ACKNOWLEDGMENTS}

We would like to thank R. J. Elovich and A. D. Peoples for their help in performing the experiments, and also D. J. Bates and B. A. Pulsipher for their help in designing and analyzing the results of the parametric study. We are also grateful to J. L. Swanson for reviewing the document, J. A. Richelieu for typing it, S. F. Liebetrau for editing it, and G. M. Brett, S. L. Ciarlo, and K. J. Defferding for preparing the graphics. We are especially grateful to E. D. Waters and R. M. Orme of Rockwell Hanford Operations for their insight, as well as their financial and moral support. 



\section{CONTENTS}

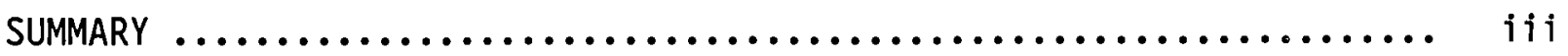

ACKNOWLEDGMENTS $\ldots \ldots \ldots \ldots \ldots \ldots \ldots \ldots \ldots \ldots \ldots \ldots \ldots \ldots \ldots \ldots \ldots \ldots \ldots$

INTRODUCTION $\ldots \ldots \ldots \ldots \ldots \ldots \ldots \ldots \ldots \ldots \ldots \ldots \ldots \ldots \ldots \ldots \ldots \ldots \ldots$

EXPERIMENTAL DESIGN, APPARATUS, ANALYTICAL METHODS, AND PROCEDURE .... 3

EXPERIMENTAL DESIGN $\ldots \ldots \ldots \ldots \ldots \ldots \ldots \ldots \ldots \ldots \ldots \ldots \ldots \ldots \ldots \ldots \ldots \ldots \ldots$

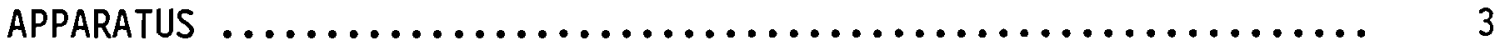

ANALYTICAL METHODS $\ldots \ldots \ldots \ldots \ldots \ldots \ldots \ldots \ldots \ldots \ldots \ldots \ldots \ldots$

EXPERIMENTAL PROCEDURE $\ldots \ldots \ldots \ldots \ldots \ldots \ldots \ldots \ldots \ldots \ldots \ldots \ldots \ldots$

RESULTS $\ldots \ldots \ldots \ldots \ldots \ldots \ldots \ldots \ldots \ldots \ldots \ldots \ldots \ldots \ldots \ldots \ldots \ldots \ldots \ldots \ldots \ldots \ldots$

GENERAL OBSERVATIONS $\ldots \ldots \ldots \ldots \ldots \ldots \ldots \ldots \ldots \ldots \ldots \ldots \ldots \ldots \ldots$

PARAMETRIC STUDY $\ldots \ldots \ldots \ldots \ldots \ldots \ldots \ldots \ldots \ldots \ldots \ldots \ldots \ldots \ldots \ldots \ldots$

TEST OF INPUT IODINE CONCENTRATION $\ldots \ldots \ldots \ldots \ldots \ldots \ldots \ldots \ldots \ldots \ldots$

TESTS OF BED LENGTH AND EXTENDED STANDBY $\ldots \ldots \ldots \ldots \ldots \ldots \ldots \ldots \ldots$

TEST OF REDUCED SILVER MORDENITE $\ldots \ldots \ldots \ldots \ldots \ldots \ldots \ldots \ldots \ldots \ldots \ldots \ldots \ldots \ldots$

CONCLUSIONS $\ldots \ldots \ldots \ldots \ldots \ldots \ldots \ldots \ldots \ldots \ldots \ldots \ldots \ldots \ldots \ldots \ldots \ldots \ldots$

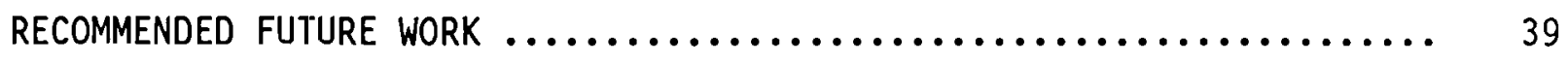

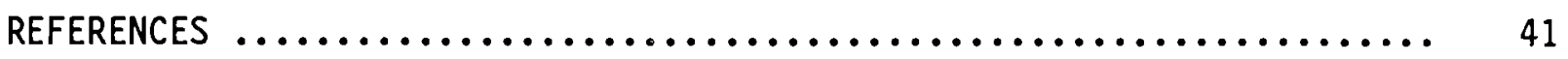

APPENDIX A - PREVIOUS AgZ - METHYL IODIDE TESTS............... A.1

APPENDIX B - AgZ DENSITY AND PRESSURE DROP MEASUREMENTS .......... B.1 


\section{FIGURES}

1 PFM Iodine Control Experimental Apparatus ................ 5

2 Effluent Concentration versus Time for Run $1 \ldots \ldots \ldots \ldots \ldots \ldots$

3 Effluent Concentration versus Time for Run $2 \ldots \ldots \ldots \ldots \ldots \ldots \ldots$

4 Effluent Concentration versus Time for Run $3 \ldots \ldots \ldots \ldots \ldots$

5 Effluent Concentration versus Time for Run $4 \ldots \ldots \ldots \ldots \ldots \ldots$

6 Effluent Concentration versus Time for Run $5 \ldots \ldots \ldots \ldots \ldots \ldots \ldots$

7 Effluent Concentration versus Iodine Loading on AgZ for Run 6

(Parametric Study) ................................. 18

8 Effluent Concentration versus Iodine Loading on AgZ for Run 7

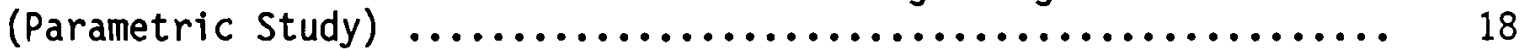

9 Effluent Concentration versus Iodine Loading on AgZ for Run 8

(Parametric Study) ................................ 19

10 Effluent Concentration versus Iodine Loading on AgZ for Run 9

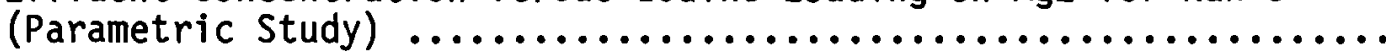

11 Effluent Concentration versus Iodine Loading on AgZ for Run 10

(Parametric Study) ................................. 20

12 Effluent Concentration versus Iodine Loading on AgZ for Run 11

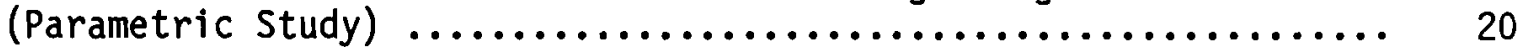

13 Effluent Concentration versus Iodine Loading on AgZ for Run 12

(Parametric Study)

14 Effluent Concentration versus Iodine Loading on AgZ for Run 13

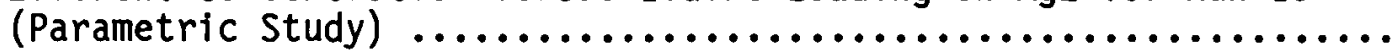

15 Effluent Concentration versus Iodine Loading on AgZ for Run 14

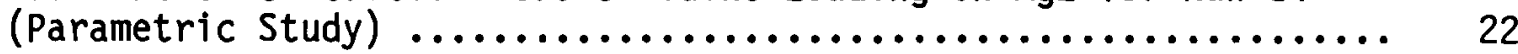

16 Effluent Concentration versus Iodine Loading of AgZ for Run 15

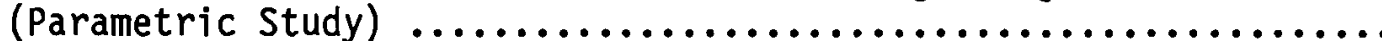

17 Effluent Concentration versus Iodine Loading on AgZ for Run 16

(Test of Input Iodine Concentration)

18 Effluent Concentration versus Time for Run 16 (Test of Input Iodine Concentration) 
19 Effluent Concentration versus Iodine Loading on AgZ for Run 18

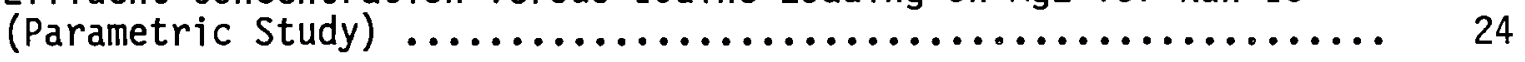

20 Average Effect of Temperature on Iodine Loading on AgZ (Parametric Study) ...................................... 24

21 Effluent Concentration versus Iodine Loading on AgZ for Run 17 (Test of Bed Length and Extended Standby) ................... 27

22 Effluent Concentration versus Iodine Loading on AgZ for Run 20 (Test of Bed Length and Extended Standby) .................... 28

23 Effluent Concentration During Standby Operation versus Iodine Loading on AgZ for Run 20 (Test of Bed Length and Extended

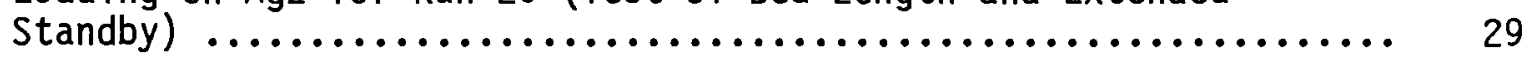

24 Effluent Concentration During Standby Operation versus Time for Run 20 (Test of Bed Length and Extended Standby) ............... 29

25 Effluent Concentration versus Iodine Loading on AgZ for Run 19

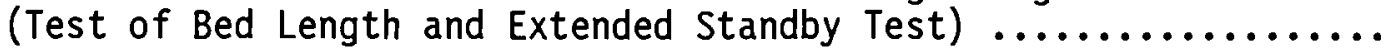

26 Effluent Concentration versus Iodine Loading on $\mathrm{Ag}^{0} \mathrm{Z}$ for Run 22

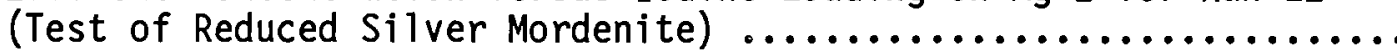

A.1 Effluent Concentration versus Iodine Loading for $18-\mathrm{cm}$ Bed of AgZ (Previous Work) 


\section{$\underline{\text { TABLES }}$}

1 Normal, Off-Normal, and Standby Operating Conditions for PFM

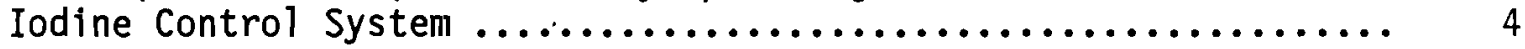

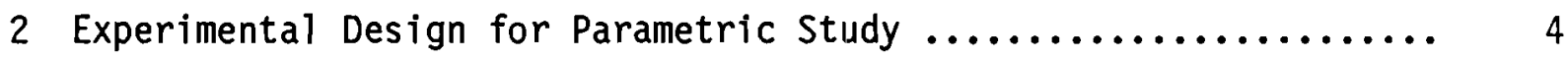

3 Standard Experimental Operating Parameters $\ldots \ldots \ldots \ldots \ldots \ldots \ldots .6 . \ldots$

4 Summary of PFM Iodine-Trapping Study Results $\ldots \ldots \ldots \ldots \ldots \ldots \ldots . . . . .12$

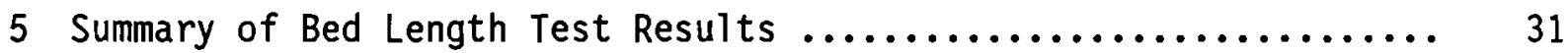

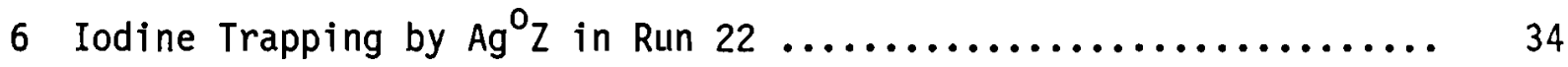

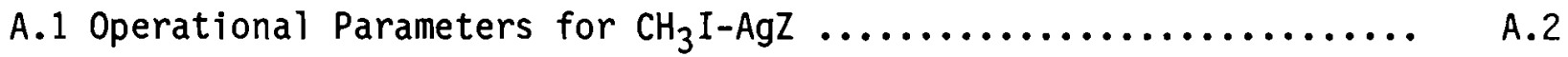

A.2 Bed Loading at Breakthrough $\ldots \ldots \ldots \ldots \ldots \ldots \ldots \ldots \ldots \ldots \ldots \ldots \ldots$ A.2

B.1 Pressure Drop in Agz Beds $\ldots \ldots \ldots \ldots \ldots \ldots \ldots \ldots \ldots \ldots \ldots \ldots \ldots$ B. 2

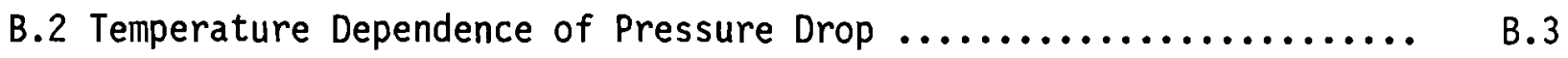




\section{INTRODUCTION}

The Process Facility Modification (PFM) is being designed for head-end treatment of irradiated fuels, including $\mathrm{N}$-Reactor and Fast Flux Test Facility (FFTF) fuels, for processing by the PUREX ${ }^{(a)}$ plant at the Hanford Site. Included in the design is a gas treatment system to remove radioiodine from the dissolver off gas. The currently proposed process uses heated beds of the silver-exchanged zeolite, silver mordenite (AgZ).

Rockwell Hanford Operations (Rockwe11), operators of the PFM and PUREX Plant, requested that the Pacific Northwest Laboratory (PNL) determine the effectiveness of the proposed iodine removal system at normal, off-normal, and standby conditions. Off-normal conditions would occur if the removal system for nitrogen oxides $\left(\mathrm{NO}_{x}\right)$ were to fail or if the $\mathrm{NO}_{x}$ removal system were to be placed downstream instead of upstream of the iodine removal system. Standby conditions would occur when the dissolver was not operating, but normal flow of iodine-free air would still pass through the off-gas system. The iodine release from the AgZ beds at standby conditions is called chronic release. The target release level for the iodine control system is $\left\langle 10^{-5} \mu \mathrm{mol} \mathrm{I} / \mathrm{L}\right.$. A previous PFM study ${ }^{(\mathrm{b})}$ demonstrated that $\mathrm{AgZ}$ would remove iodine from the gas stream, reducing the level to below $10^{-3} \mu \mathrm{mol} \mathrm{I} / \mathrm{L}$.

To determine the bed-loading capacities and the effluent iodine concentrations at normal, off-normal, and standby conditions, PNL performed a series of statistically designed parametric tests using a bed of AgZ $12 \mathrm{~cm}$ long $\times 1 \mathrm{~cm}$ diameter. In addition, tests were performed to determine the effect of bed length, the effect of a second bed, the effect of extended standby conditions, and the efficiency of hydrogen-reduced $\operatorname{AgZ}\left(A g^{\circ} Z\right)$. The results of these experiments are presented in this report.

(a) Plutonium and Uranium Recovery by EXtraction. The facility is located at the Hanford Site in southeastern Washington State.

(b) Letter report to Rockwe11 Hanford Operations by L.L. Burger, R.D. Scheele, and C.L. Matsuzaki. 1983. PFM Iodine Removal Studies, Pacific Northwest Laboratory, Richland, Washington. 
. 
EXPERIMENTAL DESIGN, APPARATUS, ANALYTICAL METHODS, AND PROCEDURE

The objective of the experimental program was to determine the efficacy of AgZ as an iodine-trapping agent at normal, off-normal, and standby operating conditions in the PFM. Table 1 presents these three operating conditions. In this section we describe the experimental design, the apparatus, and how a typical experiment or run was performed. In the appendices we present a brief description of a similar experiment performed several years ago to determine iodine loading. The appendices also contain measurements of several properties for the AgZ used, such as the density, water content, and the pressure drop at various conditions.

\section{EXPERIMENTAL DESIGN}

To measure the utility of AgZ under these possible conditions, D. J. Bates, a statistician, developed an experimental plan using a two-factorial statistical design to aid us in determining the effects of nitric oxide (NO), nitrogen dioxide $\left(\mathrm{NO}_{2}\right)$, and temperature. In this two-factorial design we used two levels of each independent variable with no replication and two runs at the mid-point levels of each variable. These latter two experiments at the center point of the experimental space are used to test for "lack-offit" of the resulting linear model for the experimental region of interest. The experimental design for the parametric study after randomization of the run order is shown in Table 2.

After the parametric study was complete, several special studies were performed to investigate other factors. These tests studied the effect of very low influent iodine concentration, bed length, extended standby operation, and the comparative efficiency of $\mathrm{Ag}^{\circ} \mathrm{Z}$.

\section{APPARATUS}

The laboratory apparatus was designed to allow simulation of the expected or potential conditions in the PFM in terms of superficial face velocity, AgZ particle size, water content in the gas stream, $\mathrm{NO}$ and $\mathrm{NO}_{2}$ 
TABLE 1. Normal, Off-Normal, and Standby Operating Conditions for PFM Iodine Control System

\begin{tabular}{|c|c|c|c|}
\hline \multirow[b]{2}{*}{ Operating Parameters } & \multicolumn{3}{|c|}{ Level } \\
\hline & Normal & Off-Normal & Standby \\
\hline Gas Composition (Dry Basis) & & & \\
\hline${ }^{N O} \times$, vol\% & 2 & 18 & 0 \\
\hline NO, vol\% & $\sim 1$ & 9 & 0 \\
\hline $\mathrm{NO}_{2}$, vol\% & $\sim 1$ & 9 & 0 \\
\hline $\mathrm{O}_{2}, \mathrm{v} 01 \%$ & 12 & 14 & 21 \\
\hline $\mathrm{N}_{2}$, vol\% & 86 & 68 & 78 \\
\hline $\mathrm{CH}_{3} \mathrm{I}, \mu \mathrm{mol} / \mathrm{L}$ & 0.1 & 0.1 & 0 \\
\hline $\mathrm{H}_{2} \mathrm{O}$, vol\% & 3 & 3 & 3 \\
\hline $\mathrm{mmol} / \mathrm{L}$ & 1.3 & 1.3 & 1.3 \\
\hline Face Velocity, m/min & 5 & 5 & 5 \\
\hline Bed Temperature, ${ }^{\circ} \mathrm{C}$ & 150 & 230 & $50-150$ \\
\hline Packing Size, Mesh & $-10+16$ & $-10+16$ & $-10+16$ \\
\hline
\end{tabular}

TABLE 2. Experimental Design for Parametric Study

Experiment No. №, Vol\% № 2, Vol\% Temperature, ${ }^{\circ} \mathrm{C}$

$\begin{array}{rllll}1 & 9 & 9 & & 230 \\ 2 & 9 & 1 & 150 \\ 3 & & 5 & 5 & 190 \\ 4 & 1 & 9 & 150 \\ 5 & 9 & 9 & 150 \\ 6 & 1 & 9 & 230 \\ 7 & 5 & 5 & 190 \\ 8 & 9 & 1 & 230 \\ 9 & 1 & 1 & 150 \\ 10 & 1 & 1 & 230\end{array}$

concentrations, and temperature. The AgZ bed design was based on previous PFM studies (Letter report, Burger, Scheele, and Matsuzaki 1983) using AgZ and earlier work using $\mathrm{Ag}^{\circ} \mathrm{Z}$ for $\mathrm{CH}_{3} \mathrm{I}$ trapping (Scheele, Burger, and Matsuzaki 
1983; Burger and Scheele 1982a). A schematic of the laboratory apparatus is presented in Figure 1, and the standard experimental operating parameters are presented in Table 3.

In designing the system and selecting the operating conditions, it was necessary to select a bed size and iodine input concentration such that the time required to load a bed to 0.4 to $0.8 \mathrm{mmol} \mathrm{I} / \mathrm{g} \mathrm{AgZ} \mathrm{(50} \mathrm{to} 100 \mathrm{mg} \mathrm{I} / \mathrm{g} \mathrm{AgZ}$ ) was an acceptably small value. To reduce the loading time, we used a smaller bed than was used in previous PNL studies (Scheele, Burger, and Matsuzaki 1983; letter report, Burger, Scheele, and Matsuzaki 1983) and a higher input iodine concentration than will be found in plant.

Even though a smaller bed and a higher iodine concentration were used, the critical PFM operating conditions were preserved. The bed had a small diameter; yet it maintained normal face velocity, and it was long enough to

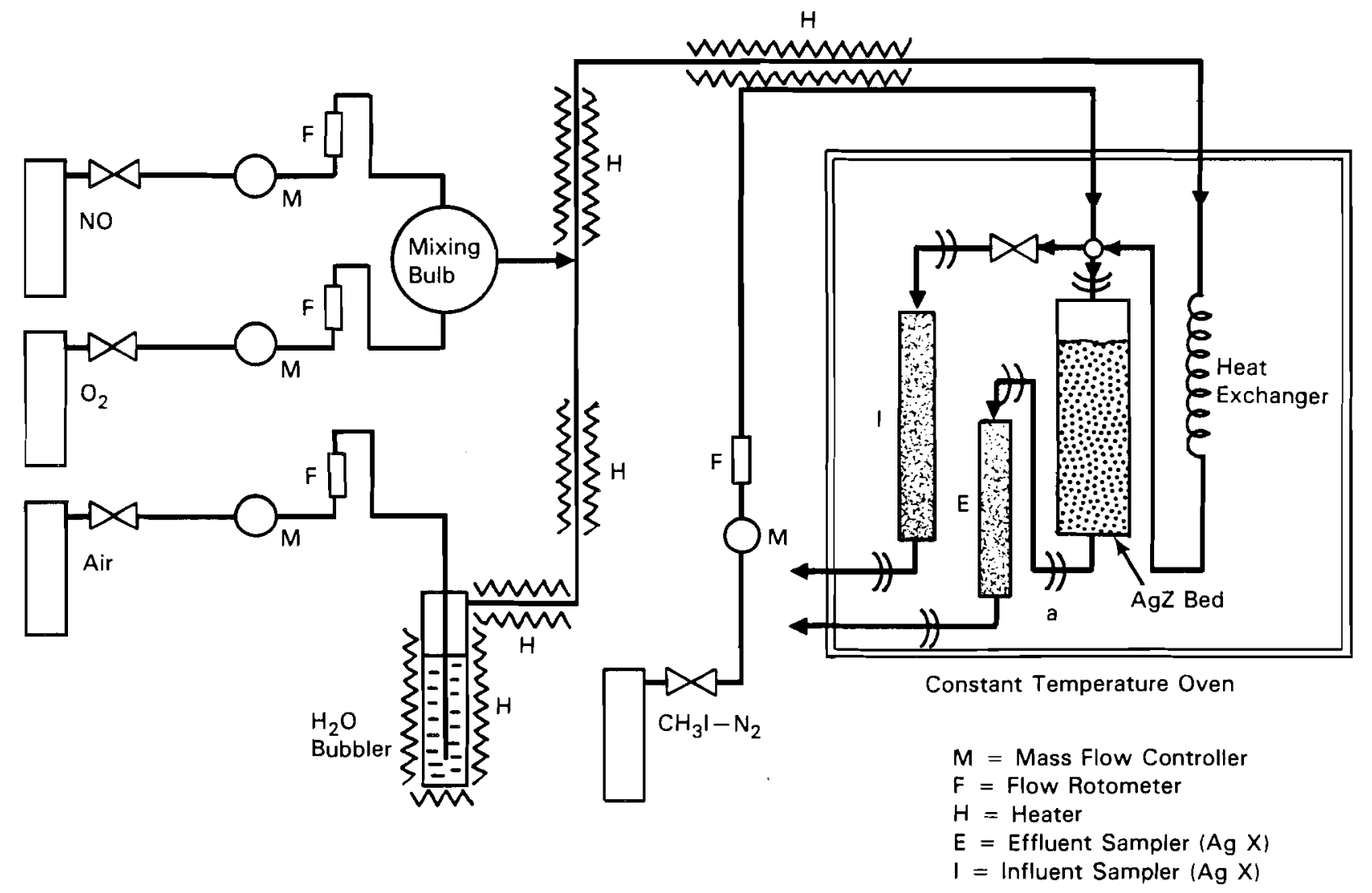

FIGURE 1. PFM Iodine Control Experimental Apparatus 
TABLE 3. Standard Experimental Operating Parameters ${ }^{(a)}$

\begin{tabular}{ll} 
Bed Parameters & \multicolumn{1}{c}{ Level } \\
\cline { 2 - 2 } Diameter & $1 \mathrm{~cm}$ \\
Length & $12 \mathrm{~cm}$ \\
Material & $\mathrm{AgZ,}-10+16 \mathrm{mesh}$ \\
$\quad$ Silver Content & $19 \mathrm{wt} \%$ \\
Weight & $9.3 \mathrm{~g}$ \\
$\quad$ Free Volume & $40 \%$ \\
Water Absorption (ambient) & $26 \mathrm{wt} \%$ \\
Input Gas Parameters & \\
Iodine Concentration & $10.5,21.0 \mu \mathrm{mol}$ \\
Carrier Gas & $\mathrm{CH} / / \mathrm{L}$ \\
Flow Rate & $\mathrm{Air}$ \\
Face Velocity & $0.44 \mathrm{~L} / \mathrm{min}$ \\
H 20 Concentration & $5.6 \mathrm{~m} / \mathrm{min}$ \\
\end{tabular}

(a) One or two parameters vary for certain
special tests.

accommodate the expected mass transfer zone of $<10 \mathrm{~cm}$ (Scheele, Burger, and Matsuzaki 1983). The input iodine concentration was also preserved, existing in the tailing edge (downstream edge) of the iodine feed band.

The typical AgZ bed was prepared by adding $9.3 \mathrm{~g}$ of AgZ (purchased presized from Ionex Corporation) to the glass column and vibrating the material to pack the AgZ particles and reduce channeling. A constant temperature oven controlled the bed temperature to about $\pm 2{ }^{\circ} \mathrm{C}$, except for momentary excursions when an iodine influent or effluent sampler was introduced or removed from the oven.

The gaseous iodine sampler traps were $1-\mathrm{cm}$ diameter by $5-\mathrm{cm}$ long columns of 1.6-mm diameter silver faujasite $(A g X)$ also purchased from Ionex. We selected $A g X$ as a trap for the low concentrations of iodine in the effluent on the basis of past experience (Burger and Scheele 1982a). Samples of the influent iodine were obtained at the beginning and end of each working day. 
The AgZ bed effluent was sampled at intervals of usually 1 to 2 hours during loading, and overnight or at selected intervals depending on the release pattern during standby.

Even though $\operatorname{AgX}$ is an excellent trap for iodine passing through or released from an $\mathrm{AgZ}$ bed, we recommended to Rockwell that AgZ be used for iodine control in the PFM because of its greater thermal stability and acid resistance compared with AgX. This greater stability is believed to be largely due to the higher Si/Al ratio (Venuto and Landis 1968) and the fact that AgX contains a clay binder.

The input gas stream was made up of air, $\mathrm{O}_{2}, \mathrm{NO}, \mathrm{CH}_{3} \mathrm{I}-\mathrm{N}_{2}$, and $\mathrm{H}_{2} \mathrm{O}$. The gases were all supplied from commercial gas cylinders. Electronic mass flow meters controlled the gas flows; calibrated rotameters were also used to monitor the flow rates. Before the air was mixed with the $\mathrm{NO}_{\mathrm{X}}$ gases, it was passed through a $40^{\circ} \mathrm{C}$ water bubbler to obtain the desired water content; tests confirmed that water saturation of the gas was obtained. The NO was passed through the mixing bulb before being mixed with the air carrier gas. A stoichiometric amount of $\mathrm{O}_{2}$ was added to the mixing bulb to react with the $\mathrm{NO}$ and produce the desired level of $\mathrm{NO}_{2}$.

Even though the reaction between pure $\mathrm{O}_{2}$ and $\mathrm{NO}$ to produce $\mathrm{NO}_{2}$ is very fast, further conversion of the remaining NO when mixed with air and at the higher temperature should be minimal because the rate drops rapidly with dilution. Kinetic calculations based on the data of Yost and Russell (1944) indicate that at the highest NO concentration and the lowest operating temperature, the NO concentration entering the bed might have been reduced by as much as $10 \%$. The amount converted will be less at the highest temperature because the reaction rate slows as temperature increases. Thus the NO and $\mathrm{NO}_{2}$ concentrations in the simulated off-gas stream were close to the desired experimental levels.

Methyl iodide was selected as the chemical form for iodine in these tests because it is the most difficult to trap of the major iodine species present in the dissolver off-gas stream, thus representing a worst case. If methyl iodide can be successfully controlled; so, then, can $\mathrm{I}_{2}$. The sources for the $\mathrm{CH}_{3} \mathrm{I}$ were two gas tanks of a mixture of $\mathrm{N}_{2}$ and ${ }^{125} \mathrm{I}$-traced $\mathrm{CH}_{3} \mathrm{I}$ obtained from New England Nuclear Corporation. The first contained 
$300 \mu \mathrm{mol} \mathrm{CH} \mathrm{CH}_{3} \mathrm{I} / \mathrm{L}$ and the second contained $154 \mu \mathrm{mol} \mathrm{CH} \mathrm{CH}_{3} \mathrm{I} / \mathrm{L}$. PNL measured the concentrations by means of gas chromatography using a 2-m Pora-Pak QS ${ }^{(a)} 80-$ 100 mesh column at $200^{\circ} \mathrm{C}$ with a He flow of $100 \mathrm{~mL} / \mathrm{min}$. A photoionization detector (PID) with a $10.5 \mathrm{eV}$ lamp was used. A concentration standard, prepared from reagent-grade $\mathrm{CH}_{3} \mathrm{I}$ and air, was used to calibrate the output of the PID.

The experimental apparatus (Figure 1) was originally designed for a face velocity through the $\mathrm{AgZ}$ bed of $5 \mathrm{~m} / \mathrm{min}$. When the experiments were to begin, Rockwell requested that we consider increasing the face velocity through the bed. Without further reduction of the bed diameter, our installed instrumentation allowed a maximum face velocity of $5.6 \mathrm{~m} / \mathrm{min}$.

The apparatus was constructed of stainless steel, glass, and plastic. The gas transfer lines were stainless or plastic outside the oven; within the oven, glass was used for the transfer lines and the bed and sampler containers. Teflon ${ }^{(b)}$ tubing and screw clamps were used to seal butted glass joints. At first, polyethylene tubing was used for a portion of the transfer line for the $\mathrm{CH}_{3} \mathrm{I}$. After the first five runs were completed, however, we discovered that the $\mathrm{CH}_{3} \mathrm{I}$ was diffusing through the tubing and was therefore not reaching the AgZ bed at the target nor at a predictable concentration. The problem was corrected by using all stainless steel tubing.

Because of the plastic tubing problem, the calculated loadings for these five runs were in error. The time-based loadings are calculated using the $\mathrm{CH}_{3} \mathrm{I}$ concentration in the tank, the flow rate, and the time to reach breakthrough. Due to the loss of $\mathrm{CH}_{3} \mathrm{I}$ through the plastic tubing, the input concentration was low, which caused the time-based loading to be high. The loadings at breakthrough based on gamma count are likely incorrect since they are calculated by correcting the measured final loading (by gamma count) using the ratio of the time to breakthrough and the total loading time as a

(a) Pora-Pak QS is a registered trademark of Waters Associates, Inc.

(b) Teflon is a registered trademark of E. I. du Pont de Nemours and Company, Inc., Wilmington, Delaware. 
correction factor. Since the input concentrations for these five runs were erratic and unknown, the correction factor will not be accurate, nor will the calculated loading at breakthrough based on gamma count.

\section{ANALYTICAL METHODS}

To provide the necessary sensitivity to measure $<10^{-5} \mu \mathrm{mol} I / L$ in the effluent concentration from the $\mathrm{AgZ}$, we used the radioactive iodine isotope ${ }^{125} \mathrm{I}$ to trace $\mathrm{CH}_{3} \mathrm{I}$ at a specific activity of $1 \mathrm{mCi} / \mathrm{mmol}$. Because of the low detection limit required, no analytical method was available to provide both quantitative measurement and identification of the effluent iodine chemical species.

To determine the iodine concentrations in the influent, in the effluent and on the beds, the gamma emission from the ${ }^{125} \mathrm{I}$ collected on the trap material and beds was counted with a NaI(TI) crystal well counter. The gamma counting was calibrated using standards prepared by two methods: 1) adding a measured volume of traced $\mathrm{CH}_{3} \mathrm{I}$ gas to a zeolite bed and 2) adding an aliquot of an aqueous $\mathrm{Na}^{125} \mathrm{I}$ standard to a zeolite bed. Because the garnma activity on the iodine-loaded AgZ beds from the experiments was too great to count without attenuation, we used a copper cup shield to attenuate the activity for these high-activity samples.

\section{EXPERIMENTAL PROCEDURE}

The following procedure was used for a typical experiment or run. To initiate a run, the oven was turned on, the air flow started, and the water bubbler heated to temperature. Water-saturated air was passed through the heated AgZ bed for 1 to 2 hours, allowing the zeolite to become saturated at its equilibrium water content. After the $\mathrm{NO}$ and $\mathrm{CH}_{3} \mathrm{I}$ lines were purged with $\mathrm{N}_{2}$, the gas flows of $\mathrm{NO}, \mathrm{O}_{2}$, and $\mathrm{CH}_{3} \mathrm{I}$ were started. The purge lines are omitted from Figure 1.

After about 1 hour with effluent trap $E$ (see Figure 1) in place at the exit of the AgZ bed, the influent trap I was installed, the valve to the trap opened, and the flow through the AgZ bed stopped by closing the flow at point (a). Influent sample times were typically 2 minutes and were taken at the beginning and end of each working day. Because of the short collection 
times, the influent concentrations measured were inaccurate and were only used to confirm that the input levels were approximately correct. They were not used to calculate bed loading. Instead, time-based loadings were calculated using known cylinder concentration, flow rate, and time. After the influent sampling was completed, an effluent trap was installed, and the valve to the influent sampler was closed and flow restarted through the AgZ bed. The effluent sampler traps were typically replaced every 1 to 2 hours throughout the working day.

At the end of the day, the $\mathrm{CH}_{3} \mathrm{I}, \mathrm{O}_{2}$, and NO flows were stopped, the NO and $\mathrm{CH}_{3} \mathrm{I}$ gas lines purged with $\mathrm{N}_{2}$, and the airflow adjusted to $5.6 \mathrm{~m} / \mathrm{min}$. An effluent trap for iodine released during standby was installed and left in place until the $\mathrm{CH}_{3} \mathrm{I}$ was restarted, or as needed to monitor the standby effluent concentration.

The progress of the iodine down the AgZ bed was tracked by monitoring the color of the iodine-loaded AgZ, which was used qualitatively to determine whether breakthrough had occurred. Another test for whether iodine had broken through was the color of the AgX effluent trap. If the trap was yellow, the color of AgI, breakthrough had occurred. At that point, the loading portion of the experiment terminated. 


\section{$\underline{\text { RESULTS }}$}

The results of the parametric study and the tests performed to determine the effect of specific factors are presented in this section. We first discuss some general observations, then the parametric study, and finally the tests of specific factors.

The results of the 21 experiments are presented in Table 4 . Table 4 presents bed loadings and the average effluent concentrations during loading and standby conditions before breakthrough. We had originally planned to define breakthrough as the point when the effluent concentration exceeded $10^{-5} \mu \mathrm{mol} \mathrm{I} / \mathrm{L}$. However, in many experiments the effluent concentration was never lower than $10^{-5} \mu \mathrm{mole} \mathrm{I} / \mathrm{L}$, so breakthrough was redefined to be the point when the effluent concentration exceeded $10^{-3} \mu \mathrm{mol} \mathrm{I} / \mathrm{L}$ after a sharp, consistent increase in the effluent iodine concentration was observed. Occasionally breakthrough occurred during nightly standby operation; in those cases, the loading at breakthrough was taken to be the loading prior to standby operation.

The bed loadings at breakthrough reported in Table 4 were determined by two methods. In one method, an integrated value was based on the time to breakthrough, the concentration in the $\mathrm{CH}_{3} \mathrm{I}$ feed tank, and the feed rate. The second method involved direct gamma counting of the loaded bed after termination of the experiment, corrected for the iodine lost during standby, and then adjusted using the ratio of the time to breakthrough to the total loading time as a correction factor.

\section{GENERAL OBSERVATIONS}

Table 4 illustrates our first general observation, that the loadings at

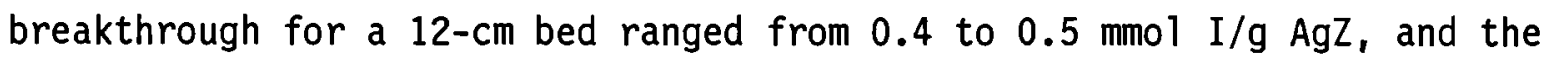
effluent iodine concentrations during loading and standby before breakthrough were routinely $10^{-4} \mu \mathrm{mol} \mathrm{I} / \mathrm{L}$ and $10^{-5} \mu \mathrm{mol} \mathrm{I} / \mathrm{L}$, respectively. The effluent concentration during iodine loading before breakthrough was greater than the target $10^{-5} \mu \mathrm{mol} \mathrm{I} / \mathrm{L}$, and the standby concentration before breakthrough (average $2 \times 10^{-5}$ ) was near this desired level. These loading results are consistent with the $0.5 \mathrm{mmol} \mathrm{I} / \mathrm{g} \mathrm{AgZ}$ loading before breakthrough measured for 


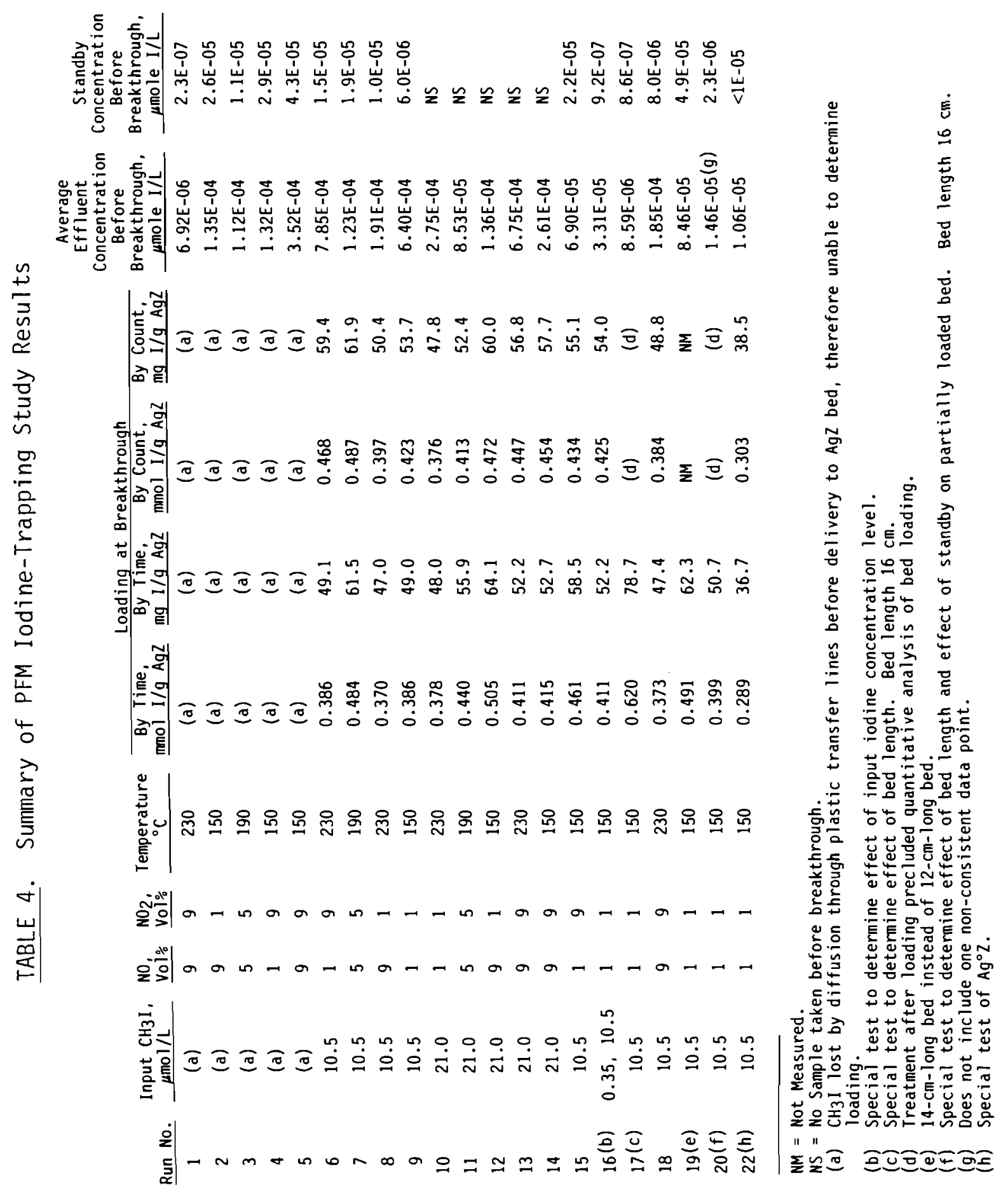


a 13-cm bed (same breakthrough criteria) in our earlier studies (letter report, Burger, Scheele, and Matsuzaki 1983). See the Appendix A for a more detailed discussion of the results of this experiment.

Our second observation was that during standby operation iodine can migrate down the bed and breakthrough can occur. As iodine is trapped by AgZ, the loaded material turns yellow and then purple. This sharply colored iodine loading band was used to monitor the progress of the iodine down the bed. During standby with iodine-free air passing through the heated bed at $5.6 \mathrm{~m} / \mathrm{min}$, the purple loading band lightened in color and moved down the bed. occasionally this migration caused breakthrough during the nightly standby operation, and the concentration would rise to a range of $10^{-1}$ to $10^{-2} \mu \mathrm{mol}$ I/L. This migration indicates that some of the iodine is labile, as previously reported by Burger and Scheele (1982b). Analytical techniques used in these earlier release experiments were not sufficiently sensitive to detect such a slow iodine bleed.

Third, by using the color of the iodine-loaded bed as a guide, we found the mass transfer zone for these experiments to be $5 \mathrm{~cm}$ or less. This figure corresponds to the mass transfer zone of $\left\langle 10 \mathrm{~cm}\right.$ measured for $\mathrm{Ag}^{\circ} \mathrm{Z}$ (Scheele, Burger, and Matsuzaki 1983) and $10 \mathrm{~cm}$ reported for $\mathrm{AgZ}$ by Thomas et al. (1977). These earlier experiments used different face velocities up to $15 \mathrm{~m} / \mathrm{min}$. Higher face velocities should cause the mass transfer zone to increase.

A fourth trend, which was observed occasionally, was that the effluent concentration decreased over the first few samples. This pattern suggests that the bed becomes more effective as it is conditioned.

\section{PARAMETRIC STUDY}

To determine the effects of $\mathrm{NO}$ concentration, $\mathrm{NO}_{2}$ concentration, and temperature on the trapping of iodine by AgZ, B. A. Pulsipher of PNL used analysis of variance methodology (ANOVA) on a selected portion of the bedloading results presented in Table 4 .

The ANOVA was performed on both the integrated loading based on time and the loading based on the gamma count of the ${ }^{125}$ I on the AgZ bed for runs 6 to 
16 and 18. After runs 6 to 15 had been completed, Pulsipher performed an ANOVA using the loading results for those experiments and suggested that run 18 be performed to provide additional information about the system. Experiment 16 was performed specifically to determine the effect of input iodine concentration; however, after considering the lack of impact of input concentration, we decided to include the loading results in the statistical analysis.

The ANOVAs were performed iteratively. If a factor was determined to be statisticaliy nonsignificant, that factor was dropped from consideration and the ANOVA repeated. For a simplified description of ANOVA, we refer the reader to Scheele, Burger and Matsuzaki (1983).

The loading curves for the first five runs and for each experiment used in the statistical analysis are presented in Figures 2 to 19. For the first five experiments and experiment 16, effluent concentration versus time is presented in Figures 2 to 6 and 18 . For the remaining experiments and experiment 16, effluent concentration versus time-based loading is presented in Figures 7 to 17 and 19. In the first five experiments, a portion of the input $\mathrm{CH}_{3} \mathrm{I}$ diffused through the plastic delivery line, which made the input concentrations extremely variable and the loadings indeterminate.

The results of the ANOVA analysis with the time-based loadings indicate that temperature has a statistically significant effect on the bed loading, while $\mathrm{NO}$ and $\mathrm{NO}_{2}$ concentration do not. As shown in figure 20, increasing temperature from 150 to $230^{\circ} \mathrm{C}$ caused an $11 \%$ reduction in the average loading for a $12-\mathrm{cm}$ bed from 0.44 to $0.39 \mathrm{mmol} \mathrm{I} / \mathrm{g} \mathrm{AgZ}$. The lack-of-fit test using the replicated center points (runs 7 and 11) indicated that the effects of temperature, $\mathrm{NO}$, and $\mathrm{NO}_{2}$ may not be strictly linear. As Figure 20 shows, the average loading at $190^{\circ} \mathrm{C}, 0.46 \mathrm{mmol} \mathrm{I} / \mathrm{g} \mathrm{AgZ}$, is higher by $5 \%$ than the average loading at $150^{\circ} \mathrm{C}$.

The statistical analysis of the data based on loading by count indicated that none of the tested factors had a significant effect. The inherent variation in the count data was of such magnitude that the small effects due 


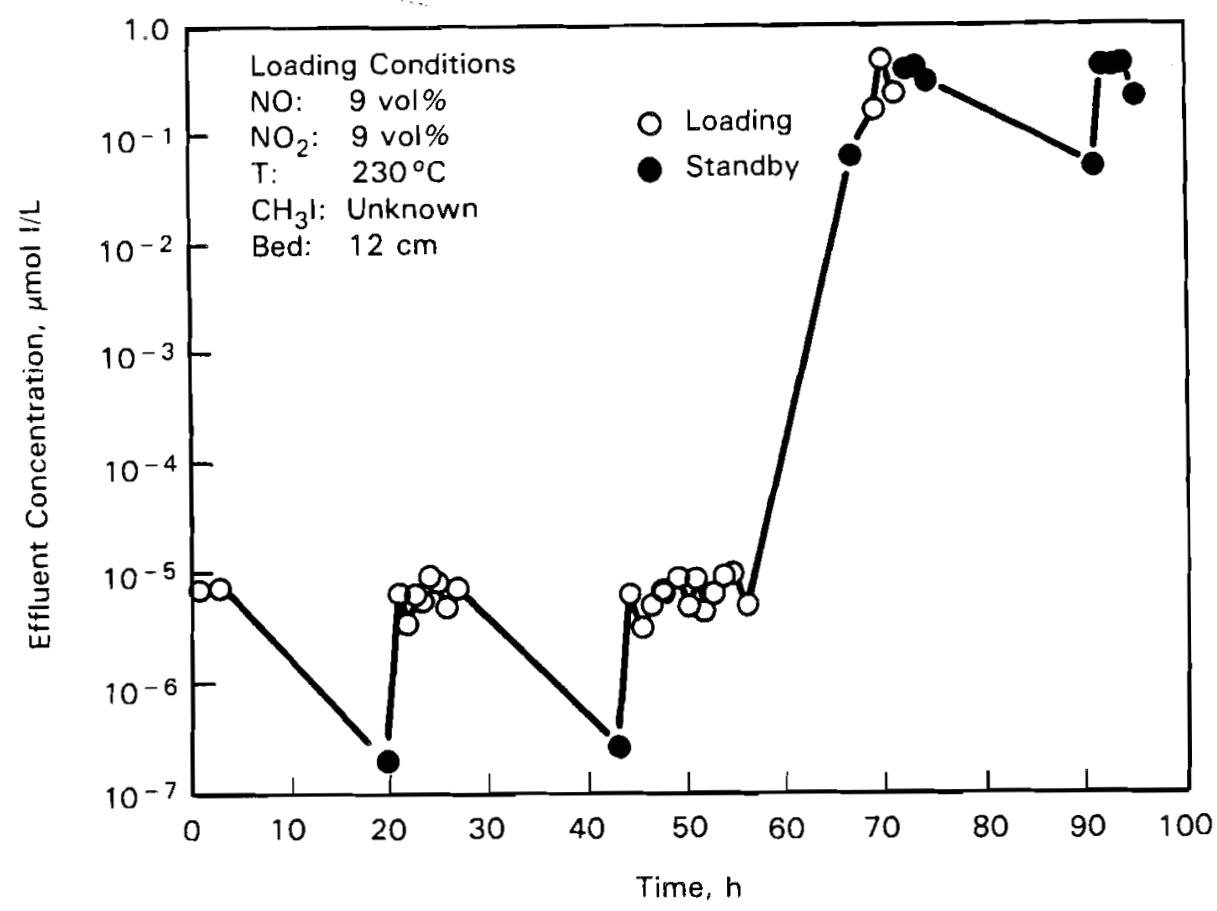

FIGURE 2. Effluent Concentration Versus Time for Run 1

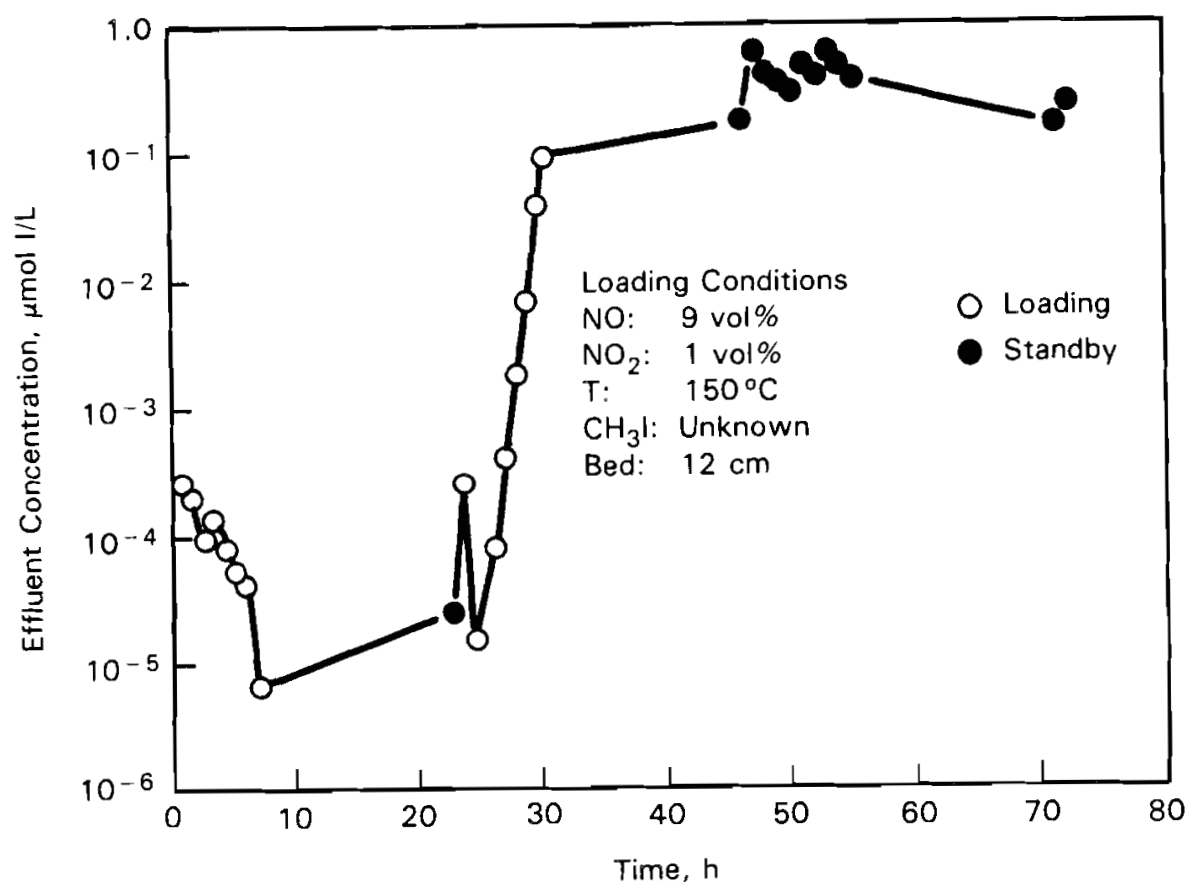

FIGURE 3. Effluent Concentration Versus Time for Run 2 


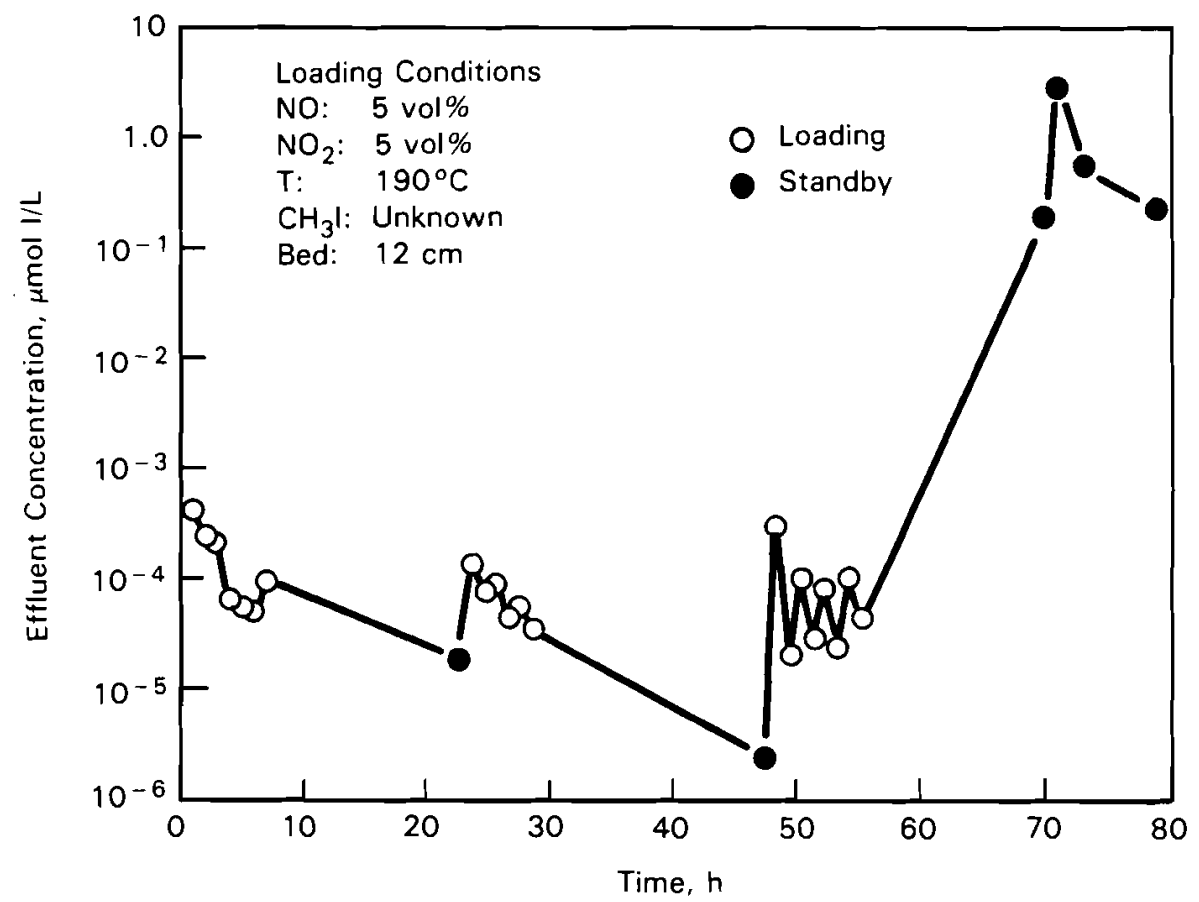

FIGURE 4. Effluent Concentration Versus Time for Run 3

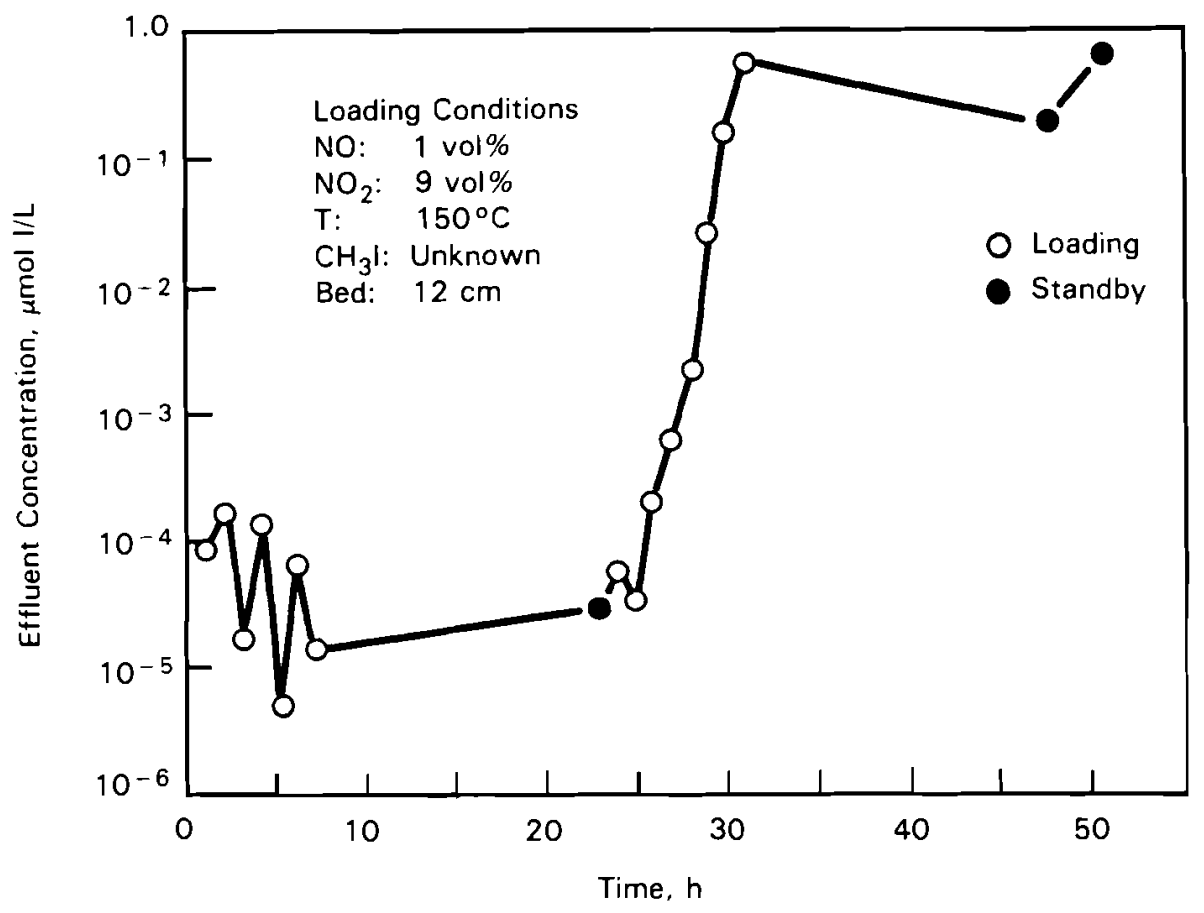

FIGURE 5. Effluent Concentration Versus Time for Run 4 


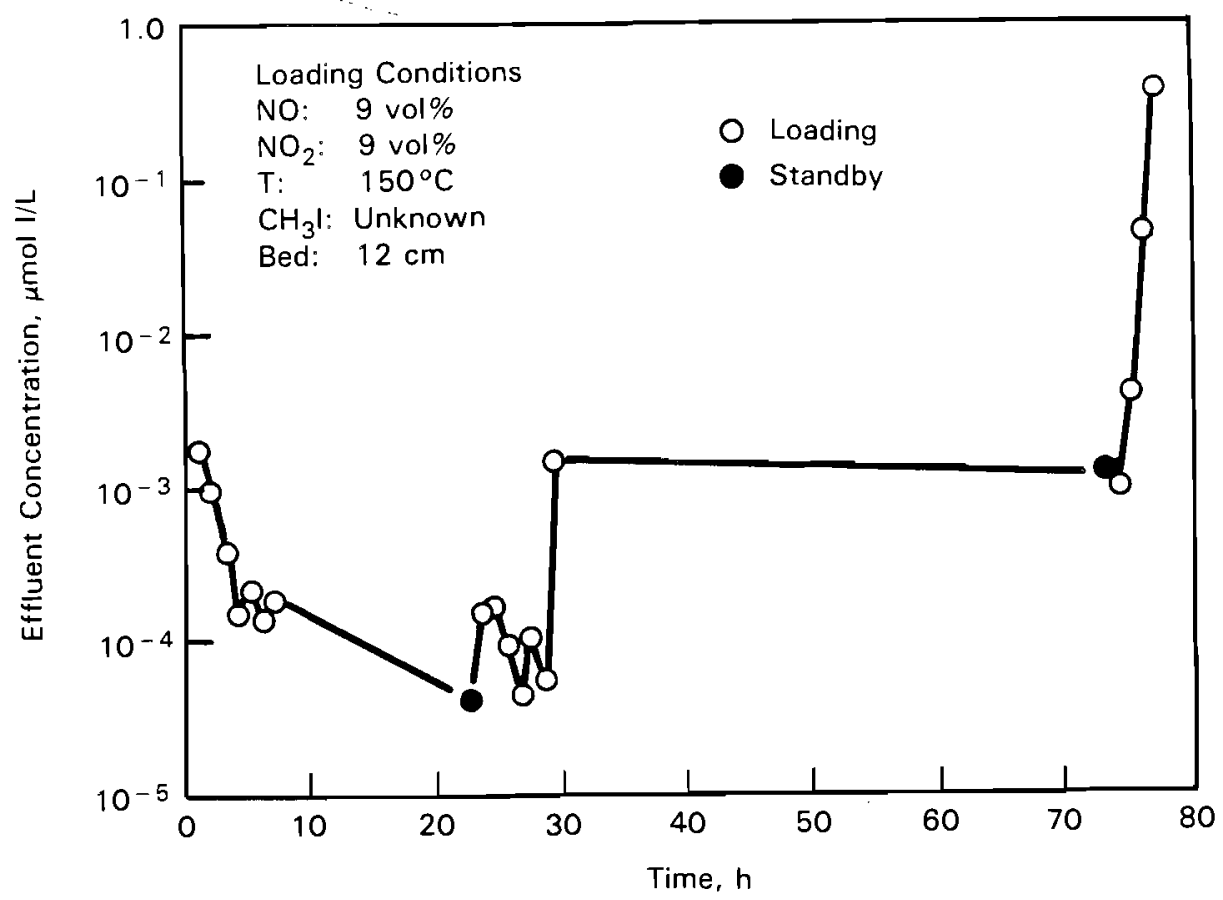

FIGURE 6. Effluent Concentration Versus Time for Run 5

to the three independent factors were not detectable. Figure 20 shows that both sets of loading data show the same trend, although the trend based on counting is less pronounced.

An attempt was made to examine statistically the effect of total $\mathrm{NO}_{\mathrm{x}}$ on the loading. For the count-based loadings, total $\mathrm{NO}_{x}$ had no significant effect. For the time-based loadings there was a suggestion of some interaction between total $\mathrm{NO}_{x}$ and temperature at the $85 \%$ confidence level. It should be noted only a trend was suggested; additional studies would be required to clarify whether there was a significant effect.

In our earlier report on $\mathrm{Ag}^{\circ} \mathrm{Z}$ (Scheele, Burger, and Matsuzaki 1983) we discussed several chemical and physical factors that could affect the sorption of iodine by silver sorbents. One factor was $\mathrm{NO}_{2}$ absorption by the zeolite with subsequent blockage of the iodine's access to the active silver sites. Another factor could involve the potential reaction between $\mathrm{NO}_{2}$ and the $\mathrm{CH}_{3} \mathrm{I}$; in our earlier studies with $\mathrm{Ag}^{\mathrm{O}} \mathrm{Z}$, we observed that when $\mathrm{NO}_{\mathrm{X}}$ was present in the gas stream the $\mathrm{CH}_{3} \mathrm{I}$ was converted to $\mathrm{I}_{2}$. It is possible that temperature and $\mathrm{NO}_{2}$ concentration have different degrees of effectiveness, each depending on the level of the other. Because of the complexity of this 


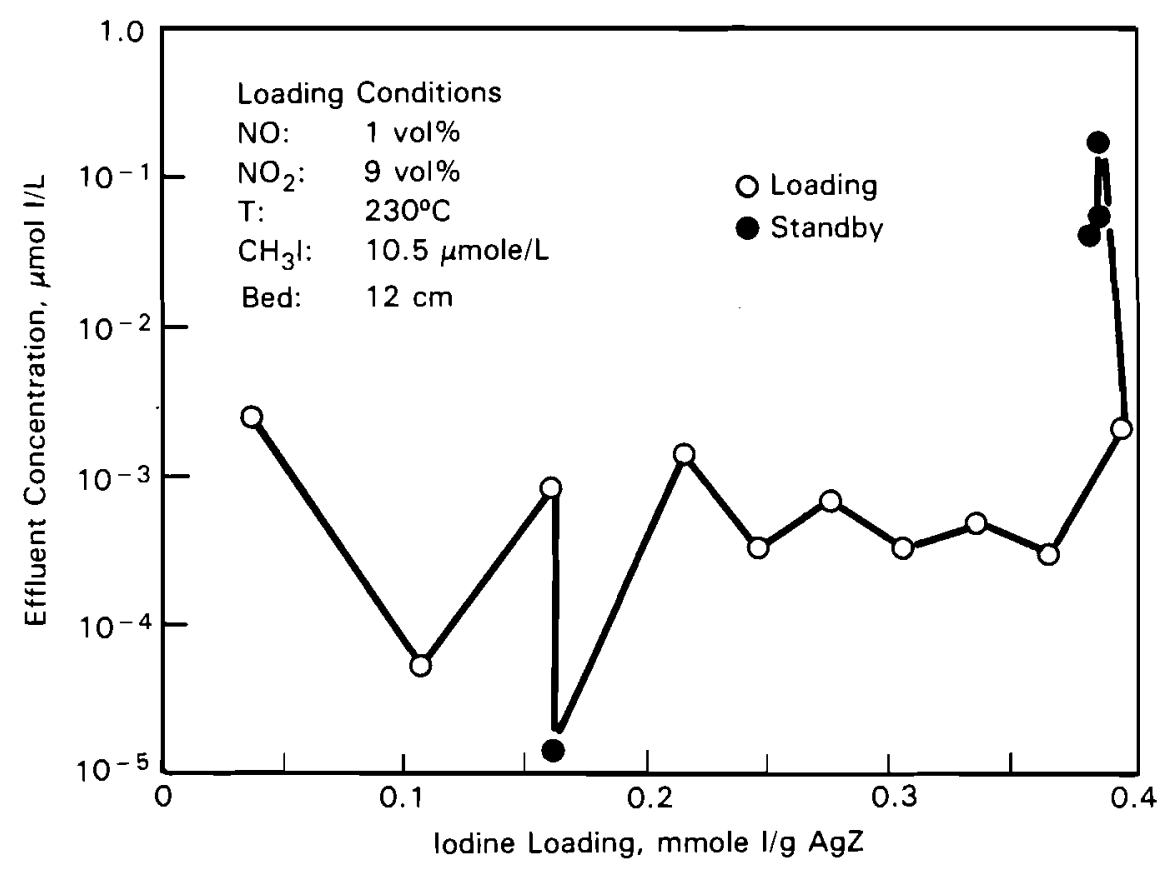

FIGURE 7. Effluent Concentration Versus Iodine Loading on AgZ for Run 6 (Parametric Study)

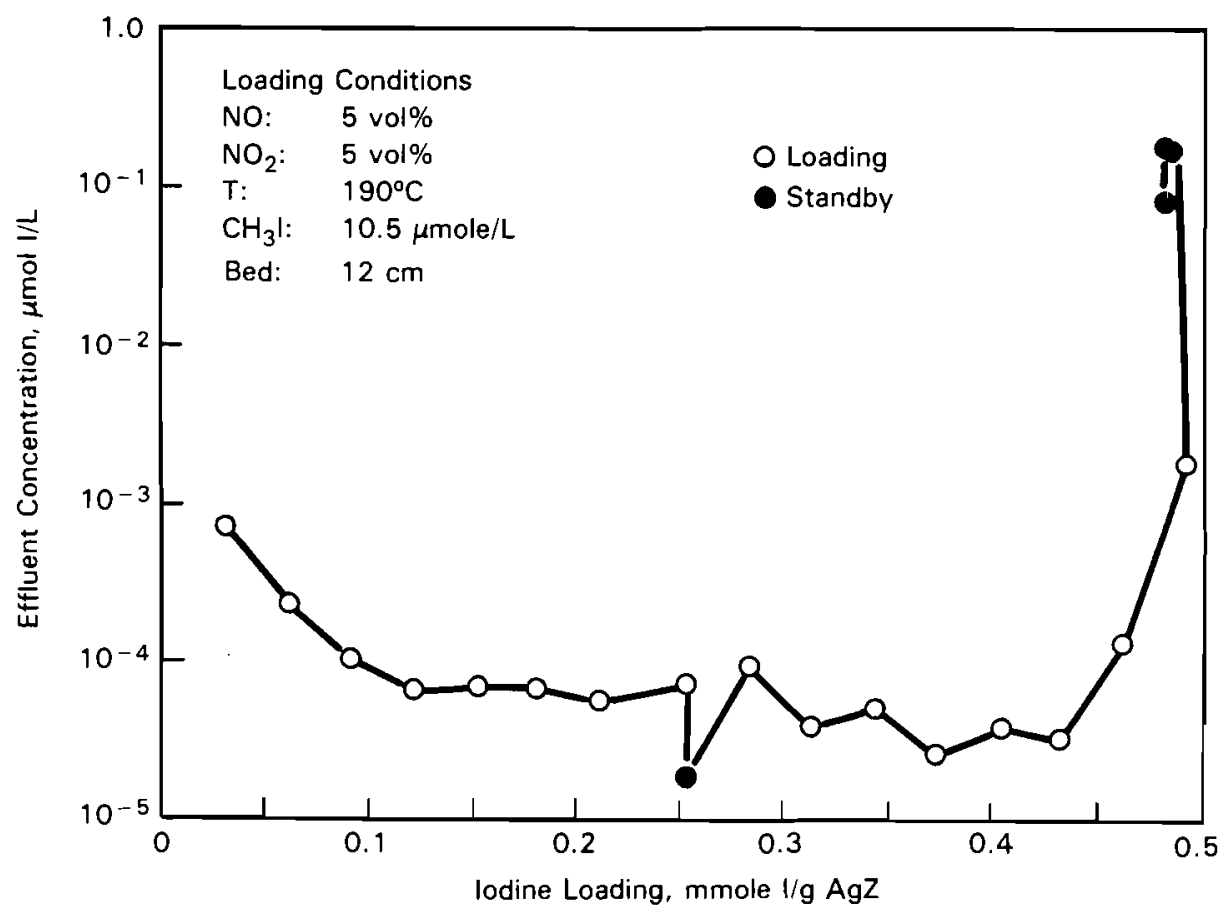

FIGURE 8. Effluent Concentration Versus Iodine Loading on AgZ for Run 7 (Parametric Study) 


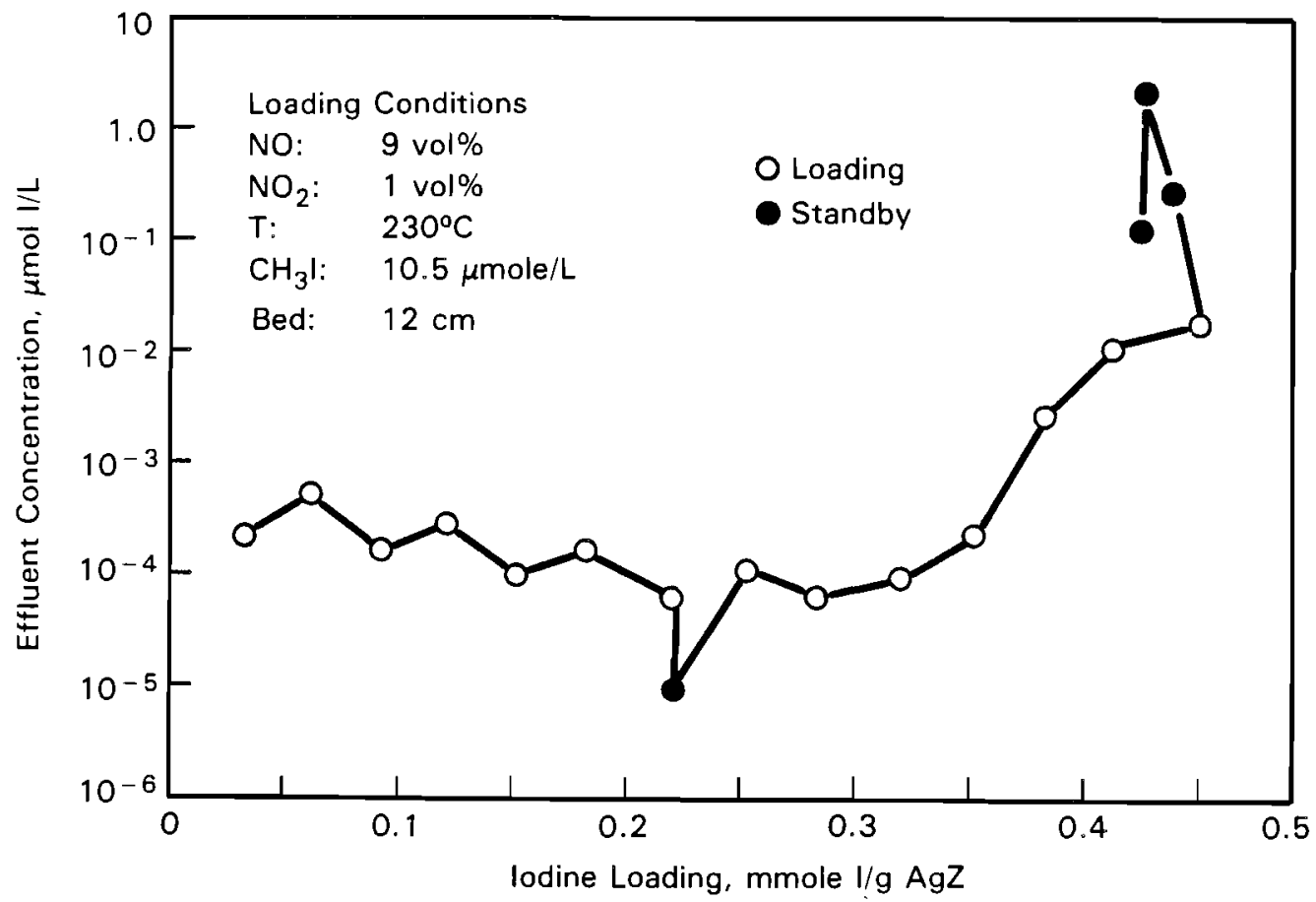

FIGURE 9. Effluent Concentration Versus Iodine Loading on AgZ for Run 8 (Parametric Study)

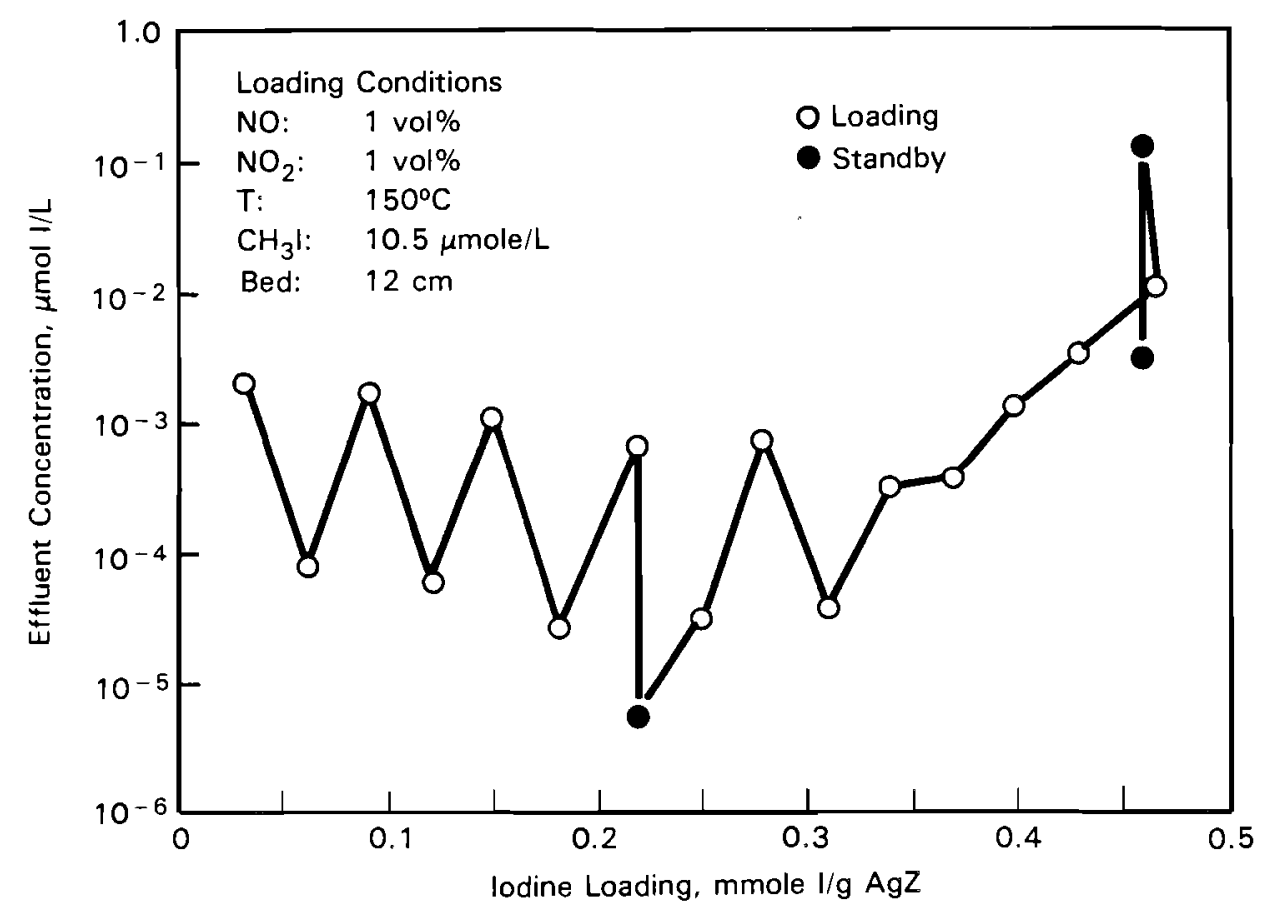

FIGURE 10. Effluent Concentration Versus Iodine Loading on AgZ for Run 9 (Parametric Study) 


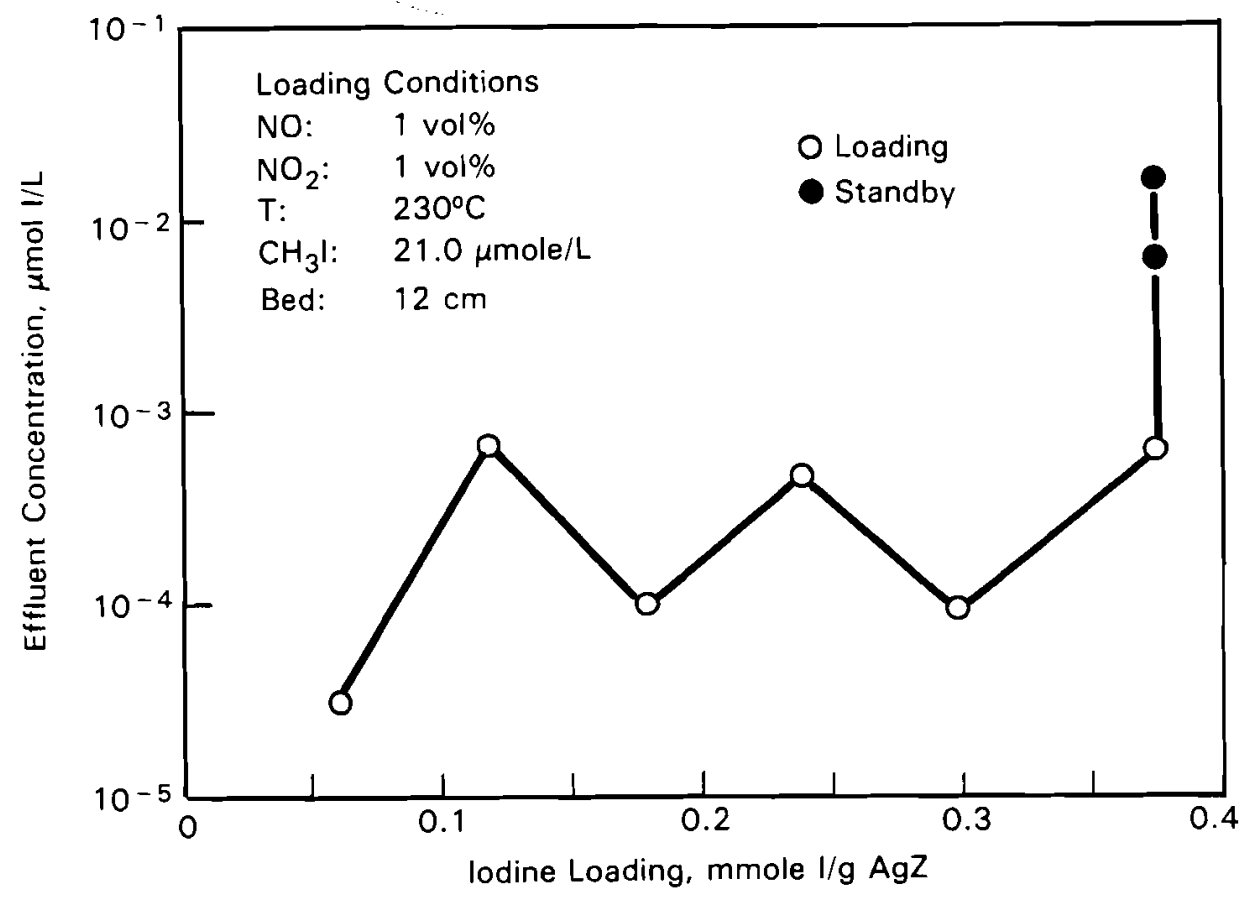

FIGURE 11. Effluent Concentration Versus Iodine Loading on AgZ for Run 10 (Parametric Study)

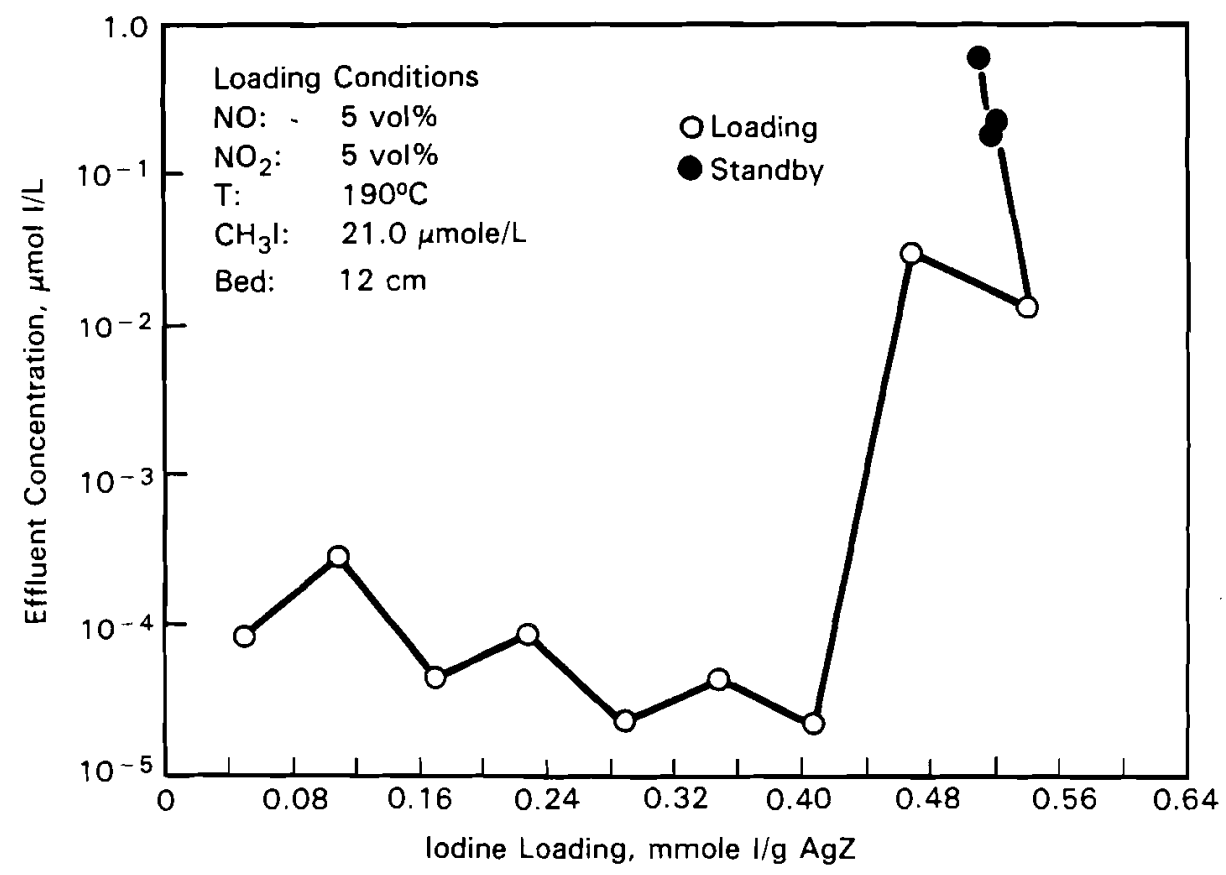

FIGURE 12. Effluent Concentration Versus Iodine Loading on AgZ for Run 11 (Parametric Study) 


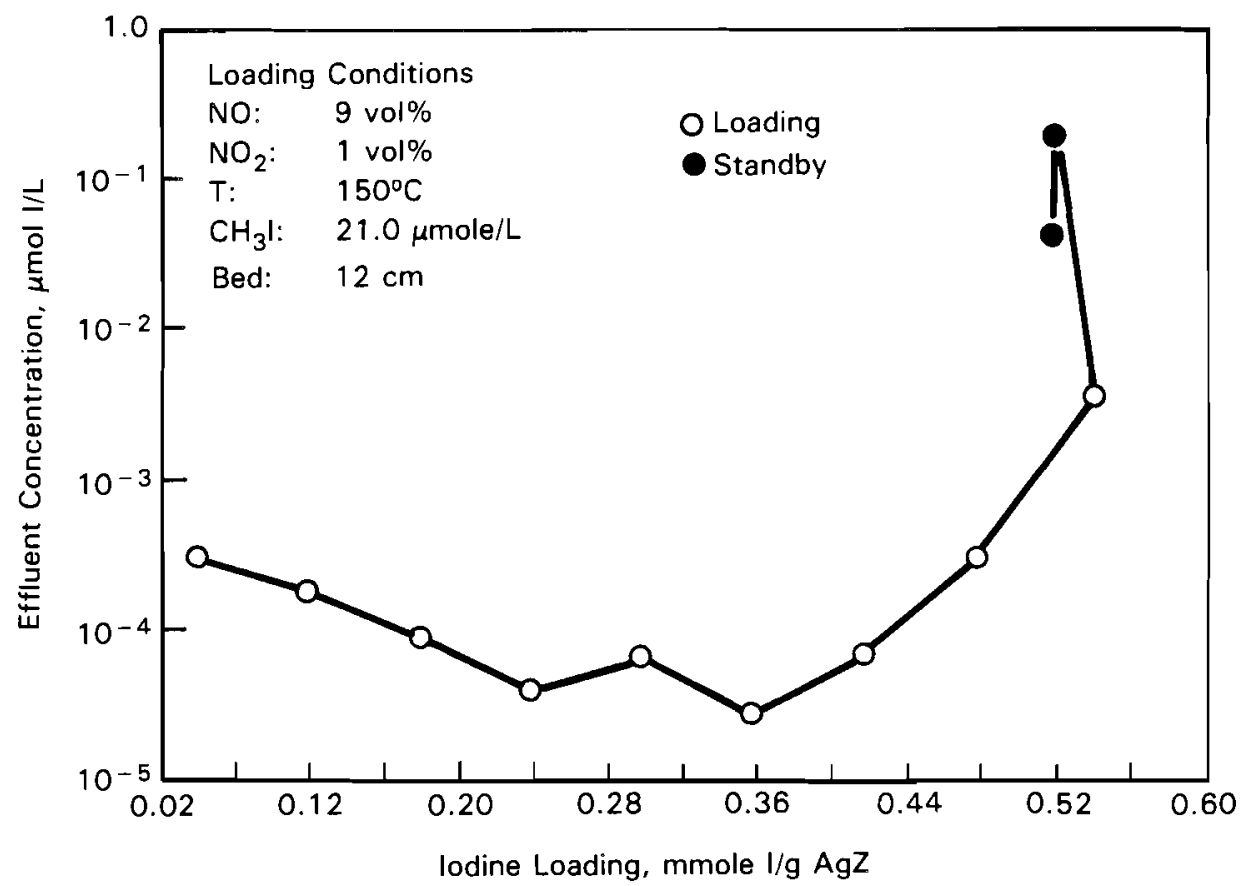

FIGURE 13. Effluent Concentration Versus Iodine Loading for Run 12 (Parametric Study)

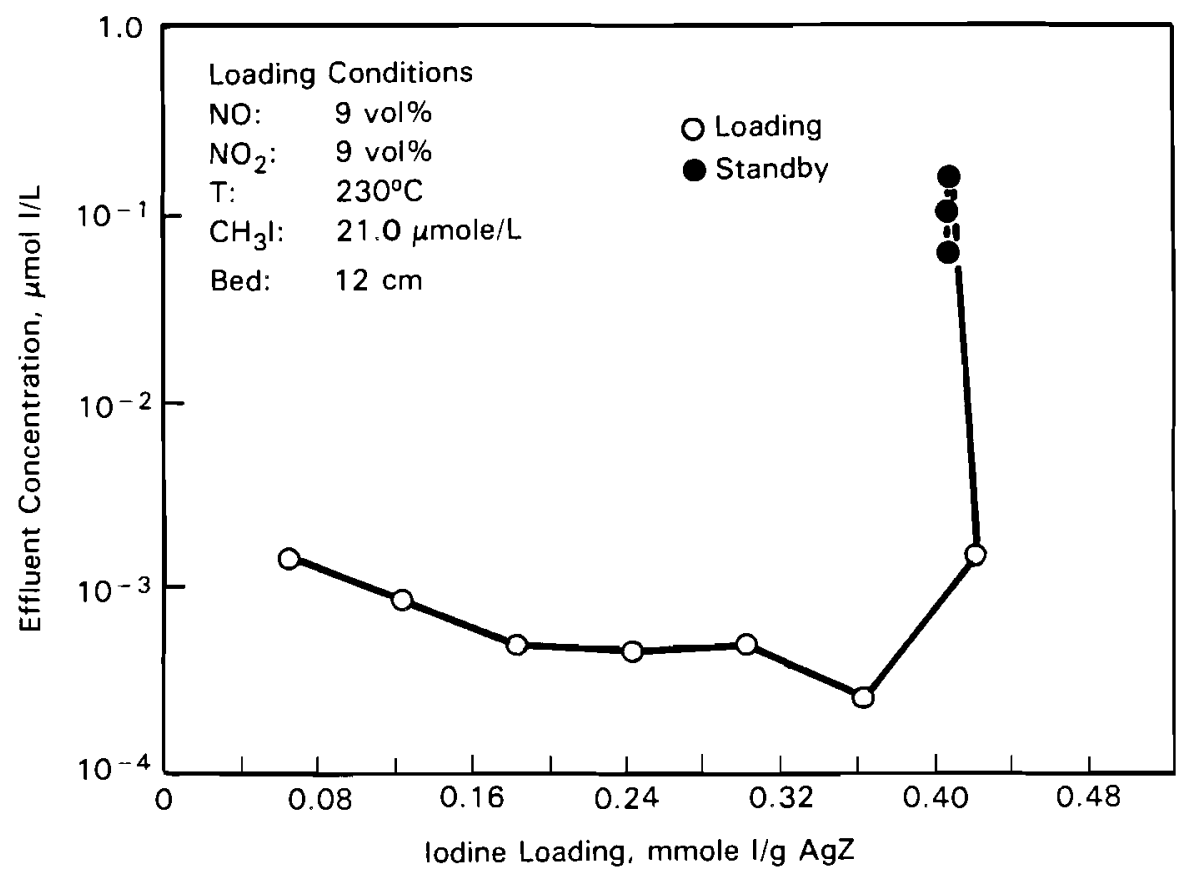

FIGURE 14. Effluent Concentration Versus Iodine Loading on AgZ for Run 13 (Parametric Study) 


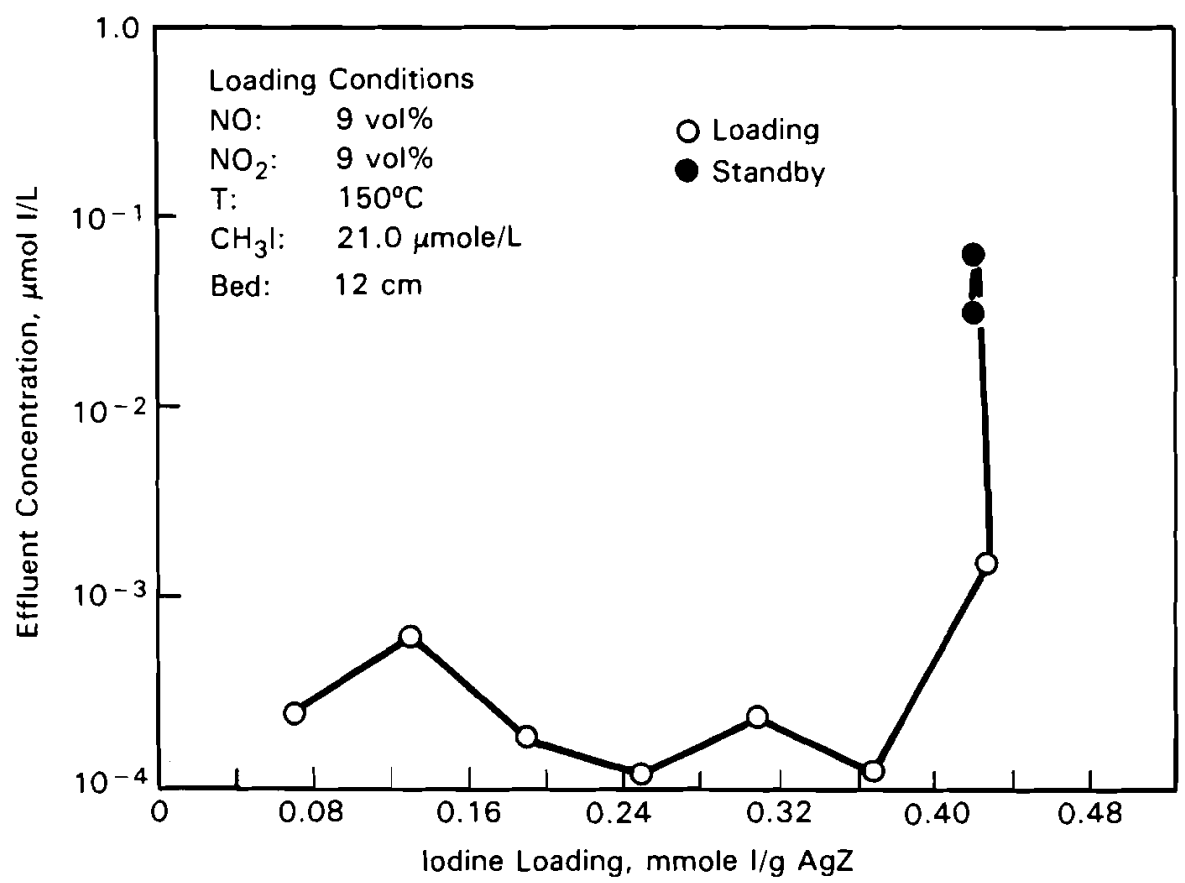

FIGURE 15. Effluent Concentration Versus Iodine Loading on AgZ for Run 14 (Parametric Study)

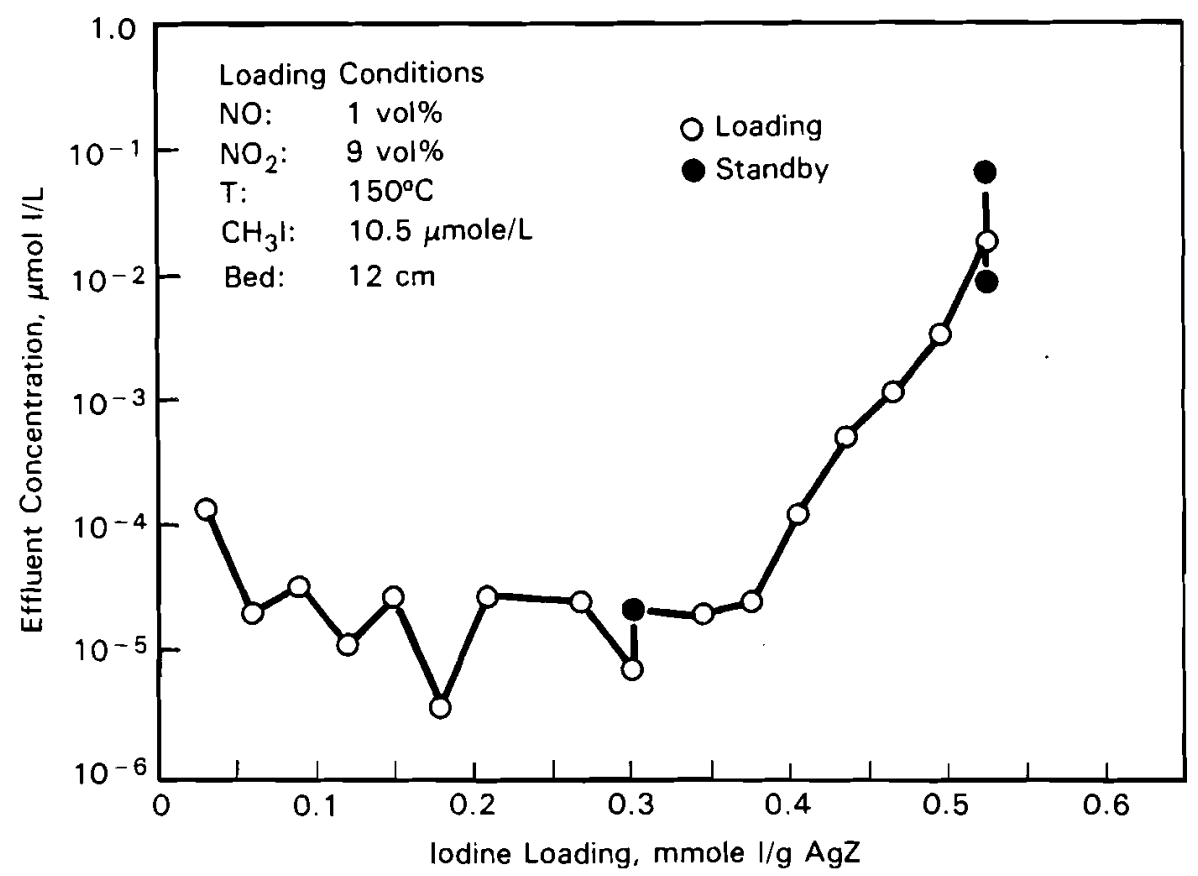

FIGURE 16. Effluent Concentration Versus Iodine Loading on AgZ for Run 15 (Parametric Study) 


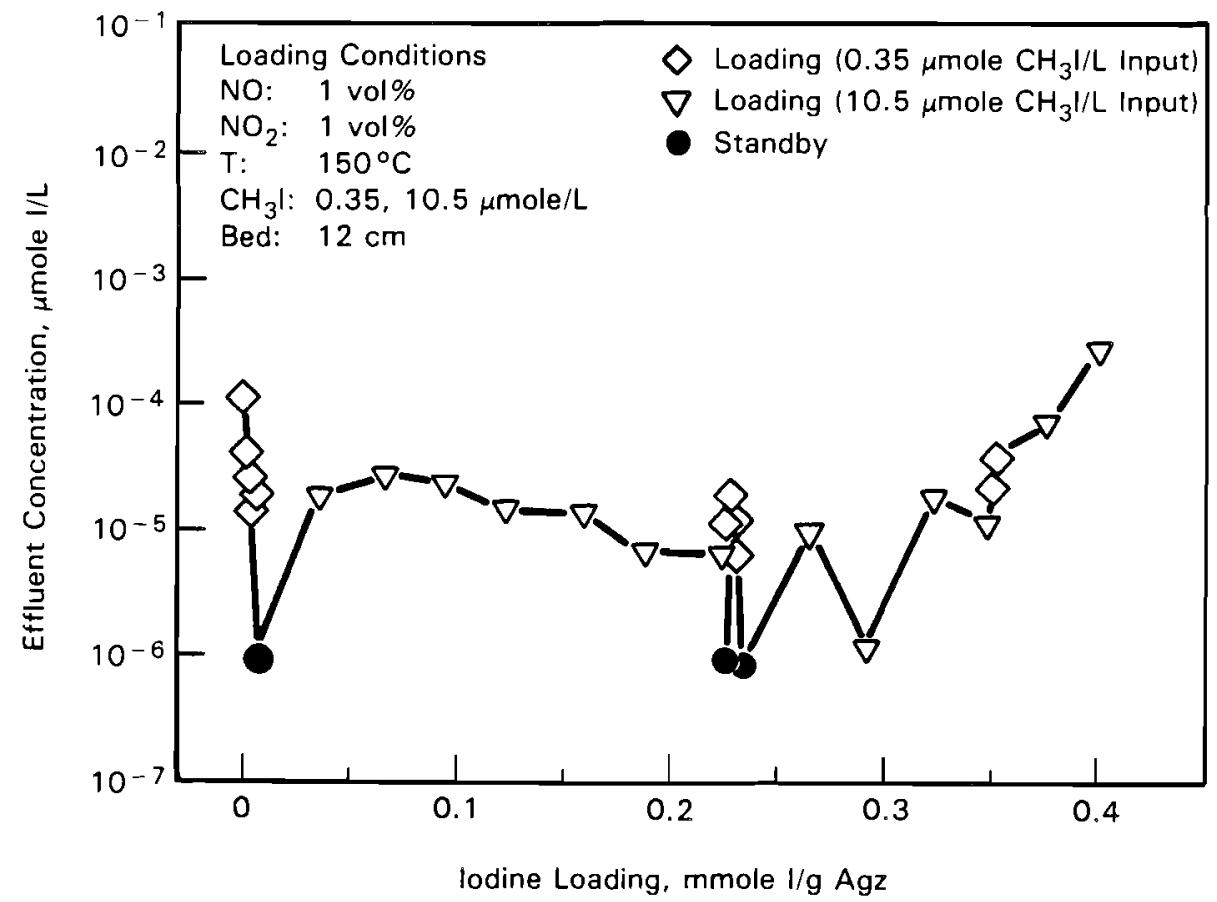

FIGURE 17. Effluent Concentration Versus Iodine Loading on AgZ for Run 16 (Test of Input Iodine Concentration).

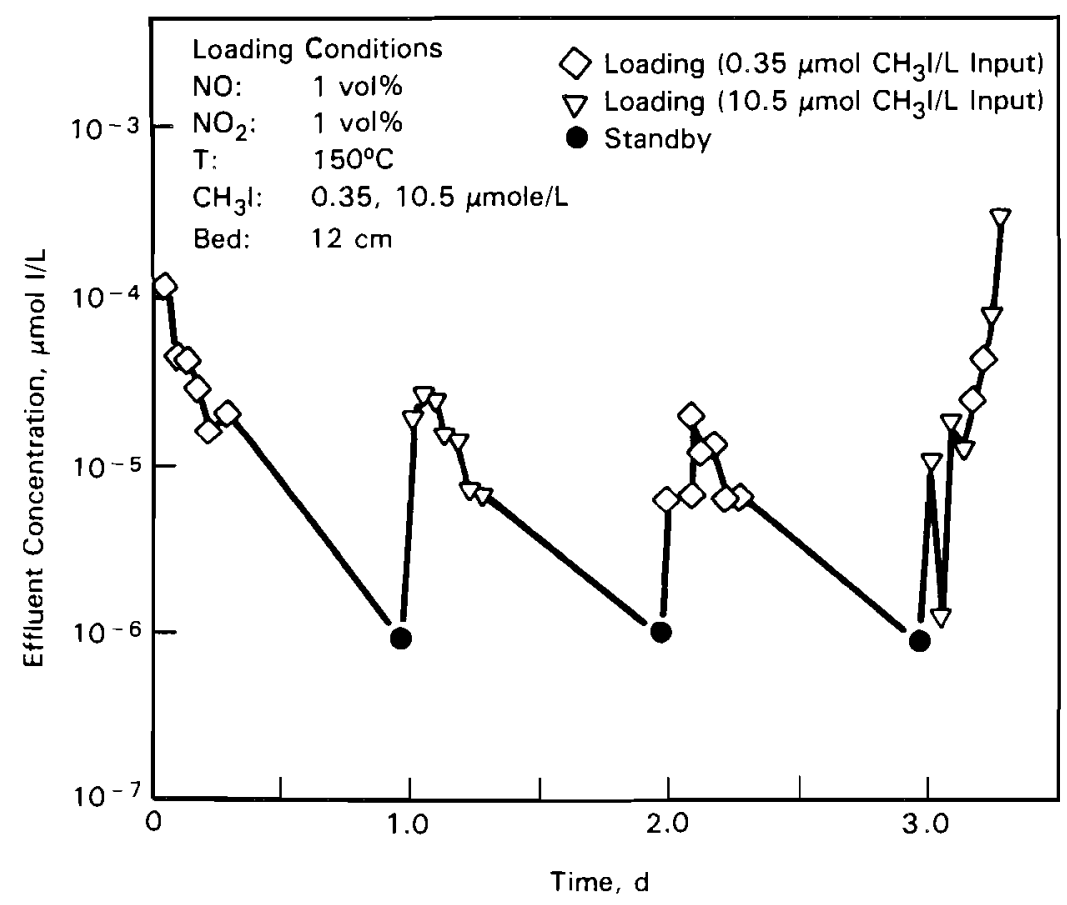

FIGURE 18. Effluent Concentration Versus Time for Run 16 (Test of Input Iodine Concentration) 


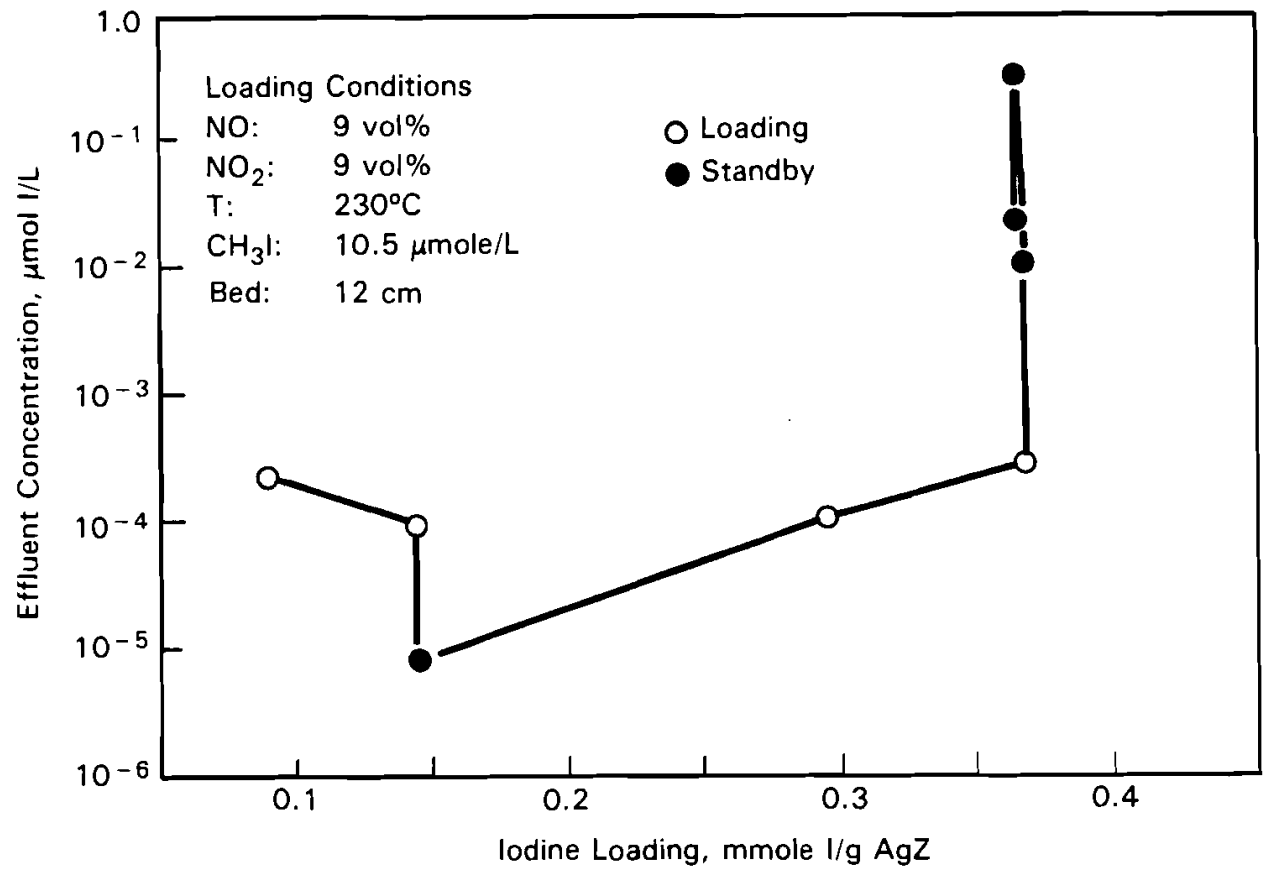

FIGURE 19. Effluent Concentration Versus Iodine Loading on AgZ for Run 18 (Parametric Study)

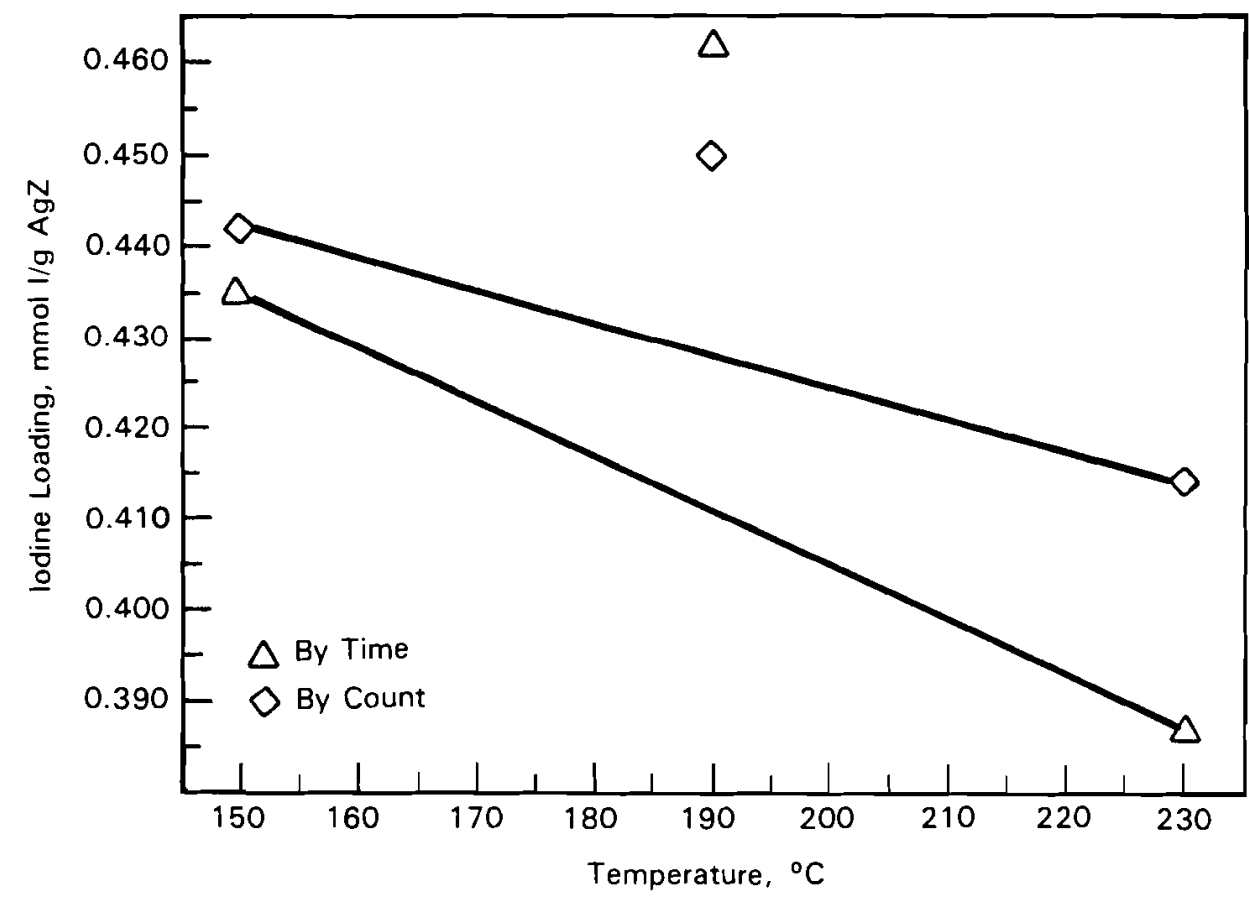

FIGURE 20. Average Effect of Temperature on AgZ Bed Loading (Parametric Study) 
system, consult our earlier detailed discussion of factors affecting the trapping of iodine by silver sorbents (Scheele, Burger, and Matsuzaki 1983).

The parametric study showed that of the factors tested, temperature was the only one to have a statistically significant effect. The reduction in time-based loading amounted to only $11 \%$ for an increase from 150 to $230^{\circ} \mathrm{C}$. Because of the lack of effect of $\mathrm{NO}_{x}$ concentration, it appears that if the iodine removal system were to be $\mathrm{placed}$ in front of the $\mathrm{NO}_{\mathrm{x}}$ recovery unit or if this unit were to fail, the loading would not be severely affected.

\section{TEST OF INPUT IODINE CONCENTRATION}

The purpose of experiment 16 was to determine whether input $\mathrm{CH}_{3} \mathrm{I}$ concentration, in the range 0.3 to $10 \mu \mathrm{mol} / \mathrm{L}$, affected the loading or the effluent concentration. Figures 17 and 18 present the effluent concentration as a function of the time-based loading and time, respectively. Figure 18 is presented to allow easier comparison between the loading periods for the two concentrations.

In experiment 16, the influent concentration of $\mathrm{CH}_{3} \mathrm{I}$ was varied between 0.35 and $10.5 \mu \mathrm{mol} / \mathrm{L}$ on alternating days for the first three days. On day 4 the starting concentration was $10.5 \mu \mathrm{mol} / \mathrm{L}$ for the first 3 effluent samples; the input concentration was changed to $0.35 \mu \mathrm{mol} / \mathrm{L}$ for the next two samples, and finally back to $10.5 \mu \mathrm{mol} / \mathrm{L}$ for the remaining samples. As can be seen from Figures 17 and 18, the experiment was terminated before breakthrough was reached, al though it appears to have been imminent. The final loading of $0.41 \mathrm{mmol} \mathrm{I} / \mathrm{g} \mathrm{AgZ}$ is reported in Table 4 as the loading at breakthrough.

As Figures 17 and 18 illustrate, the effluent concentrations during loading were near the target $10^{-5} \mu \mathrm{mol} \mathrm{I} / \mathrm{L}$ independent of the input concentration. The standby concentrations were nominally $10^{-6} \mu \mathrm{mol} \mathrm{I} / \mathrm{L}$, which is below the target effluent concentration.

Experiment 9 was performed at the same conditions as experiment 16, differing only in input iodine concentrations. For these two experiments the loadings at breakthrough are comparable, 0.39 and $0.41 \mathrm{mmol} \mathrm{I} / \mathrm{g} \mathrm{AgZ}$, respectively. However, the average effluent concentration before 
breakthrough for run $16,3 \times 10^{-5} \mu \mathrm{mol} \mathrm{I} / \mathrm{L}$ is $5 \%$ of the average effluent concentration before breakthrough for experiment 9. We have no explanation for the difference in the two effluent concentrations.

Because the loading for experiment 16 was nearly the same as that for experiment 9, we included experiment 16 in the statistical analysis. The similarity in loadings is somewhat surprising considering that there were three standby operations in experiment 16 and one in experiment 9. One would predict, from the observed mobility of sorbed iodine during standby operation, observed in other runs, that increasing the amount of standby time would lessen the final loading at breakthrough. The length of the mass transfer zone may be the controlling factor. Additional testing is required to understand this phenomenon.

In summary, this experiment shows that at a bed temperature of $150^{\circ} \mathrm{C}$, 1 vol\% $\mathrm{NO}$ and 1 vol\% $\mathrm{NO}_{2}$ in the input gas, the bed loading and effluent concentration are independent of the input $\mathrm{CH}_{3} \mathrm{I}$ concentration in the range 0.35 to $10.5 \mu \mathrm{mol} / \mathrm{L}$.

\section{TESTS OF BED LENGTH AND EXTENDED STANDBY}

After the initial phase of the parametric study was completed, we performed experiments 17 and 20 using a $16-\mathrm{cm}$ bed at normal conditions to determine the effect of a longer bed and the stability during extended standby operations of the iodine trapped on the AgZ. These tests also simulated the scenario in which the PFM dissolver is not operated and a fully or nearly fully loaded AgZ bed is maintained at standby for an extended period of time before being removed. In addition to the two planned longerbed tests, in run 19 we accidentally used a $14-\mathrm{cm}$ bed instead of a $12-\mathrm{cm}$ bed. Because this experiment provides additional information on the effect of a longer bed, it is discussed along with experiments 17 and 20 in this section.

Experiment 17 was performed in two parts. In the first part of experiment 17, as can be seen in Figure 21, a $16-\mathrm{cm}$ bed was loaded to $0.62 \mathrm{mmol} \mathrm{I} / \mathrm{g} \mathrm{AgZ}$ with a nominal effluent concentration of $10^{-5} \mu \mathrm{mol} \mathrm{I} / \mathrm{L}$ before breakthrough. These loading and effluent concentration results were encouraging. When the bed length was increased from 12 to $16 \mathrm{~cm}$, the loading at breakthrough increased $50 \%$ compared to the average loading of 


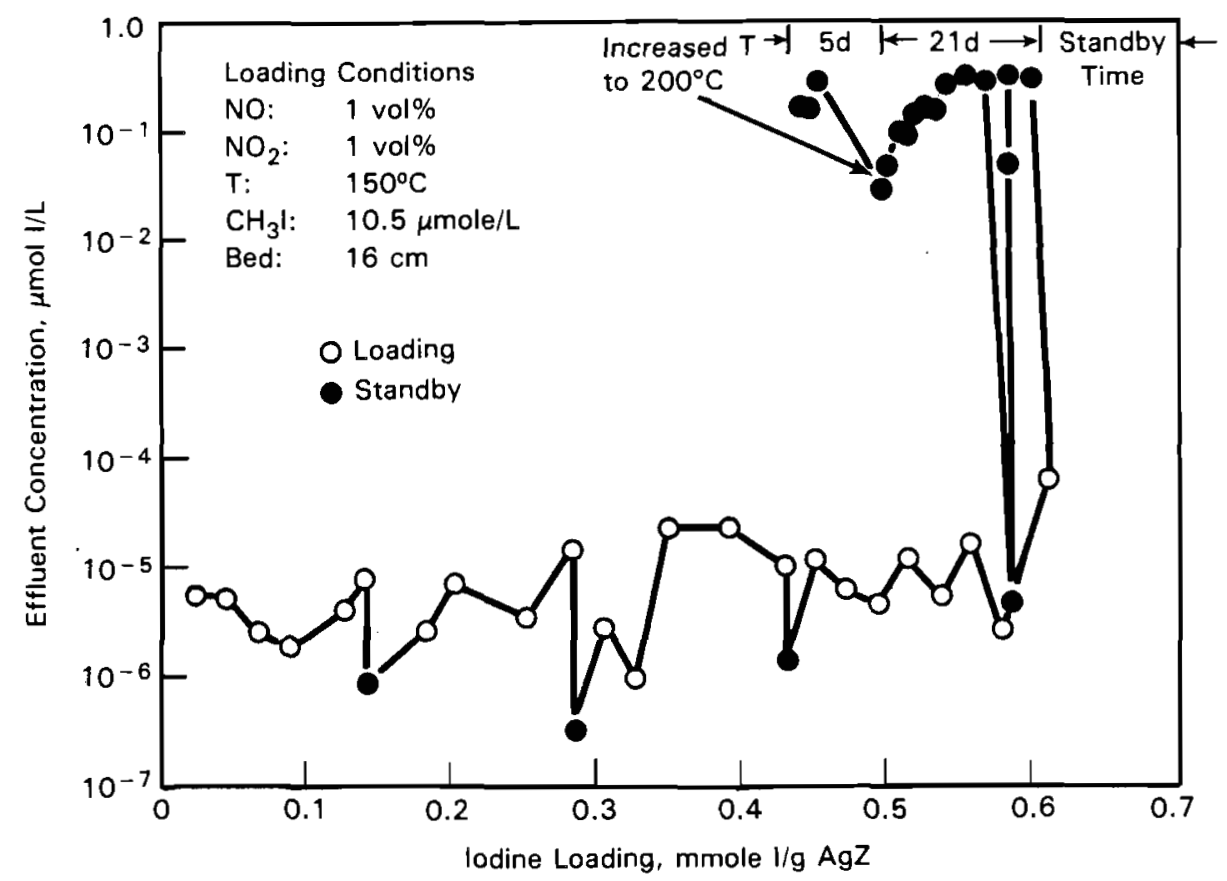

FIGURE 21. Effluent Concentration Versus Iodine Loading on AgZ for Run 17 Loading and Standby Operations (Test of Bed Length and Extended Standby)

$0.4 \mathrm{mmol} \mathrm{I} / \mathrm{g} \mathrm{AgZ}$ for experiments 9 and 16. In addition, the effluent concentration for the $16-\mathrm{cm}$ bed met the target effluent concentration established for the PFM.

In the second part of experiment 17 , the standby release was monitored for an extended period in two stages. In the first stage the chronic release was monitored for 20 days and the bed temperature was maintained at $150^{\circ} \mathrm{C}$; then the temperature was increased to $200^{\circ} \mathrm{C}$. With time, the effluent concentration at $150^{\circ} \mathrm{C}$ began to decrease with respect to the loading level. Extrapolating these standby data suggests that the bed might have stabilized at a loading of $0.5 \mathrm{mmol} \mathrm{I} / \mathrm{g} \mathrm{AgZ}$, with a chronic release at $\left\langle 10^{-5} \mu \mathrm{mol} \mathrm{I} / \mathrm{L}\right.$. Increasing the temperature to $200^{\circ} \mathrm{C}$ increased the chronic release level to $0.1 \mu \mathrm{mol} I / L$ suggesting an increase in the iodine vapor pressure.

In the second stage of the extended standby test, the bed was removed and divided into three parts of $4.93 \mathrm{~g}$ (inlet), $4.38 \mathrm{~g}$ (middle), and $3.81 \mathrm{~g}$ (outlet). The iodine loadings based on gamma count were $0.57,0.44$, and 0.35 $\mathrm{mmol} \mathrm{I} / \mathrm{g} \mathrm{AgZ}$, respectively, for the three bed portions. About $20 \%$ of the 
original trapped iodine had been removed from the bed by standby operation. After the inlet third was treated for 11 days with an airflow of $200 \mathrm{~mL} / \mathrm{min}$ at 180 to $200^{\circ} \mathrm{C}$, the effluent dropped to the target release level of $10^{-5} \mu \mathrm{mol} \mathrm{I} / \mathrm{L}$. The inlet bed loading was now $0.43 \mathrm{mmol} \mathrm{I} / \mathrm{g} \mathrm{AgZ}$. This test suggested that if a $16-\mathrm{cm}$ bed is loaded to a maximum of $0.43 \mathrm{mmol} \mathrm{I} / \mathrm{g} \mathrm{AgZ}$, the iodine loaded onto the bed might be fixed on the AgZ and might only allow an effluent concentration of $\left\langle 10^{-5} \mu \mathrm{mol} \mathrm{I} / \mathrm{L}\right.$. Experiment 20 was performed to test this hypothesis.

In experiment 20 , a $16-\mathrm{cm}$ bed was loaded to $0.40 \mathrm{mmol} \mathrm{I} / \mathrm{g} \mathrm{AgZ}$ and exposed to standby conditions for an extended period. After 7 days we inserted a second $16-\mathrm{cm}$ bed in the effluent of the first bed to determine whether increasing the bed length further reduced the effluent concentration. The effluent concentration during loading as a function of bed loading is presented in Figure 22. The chronic release levels as functions of bed loading and time are presented in Figures 23 and 24, respectively.

During the loading cycle of experiment 20 , the standby and loading effluent concentrations were similar to those for experiment 17. The loading

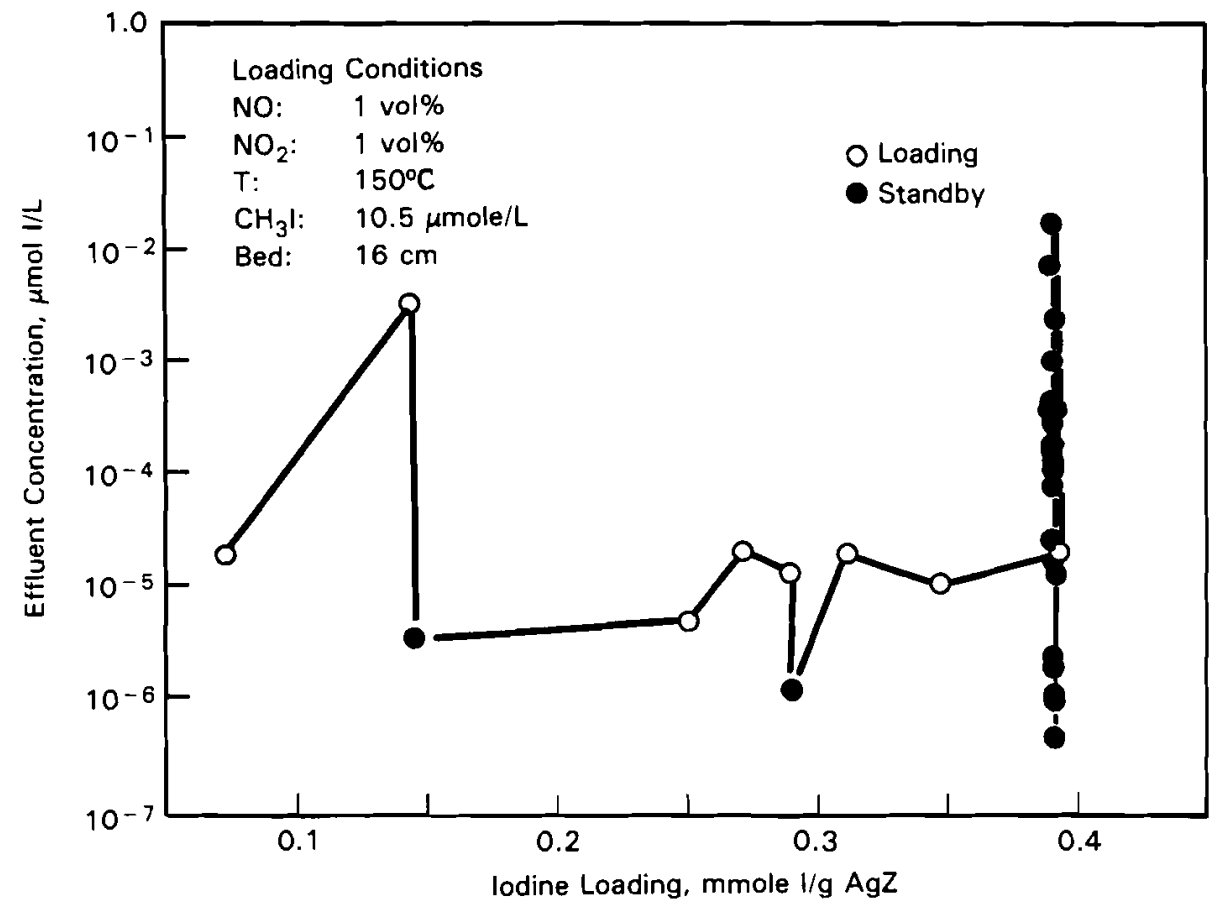

FIGURE 22. Effluent Concentration Versus Iodine Loading on AgZ for Run 20 (Test of Bed Length and Extended Standby) 


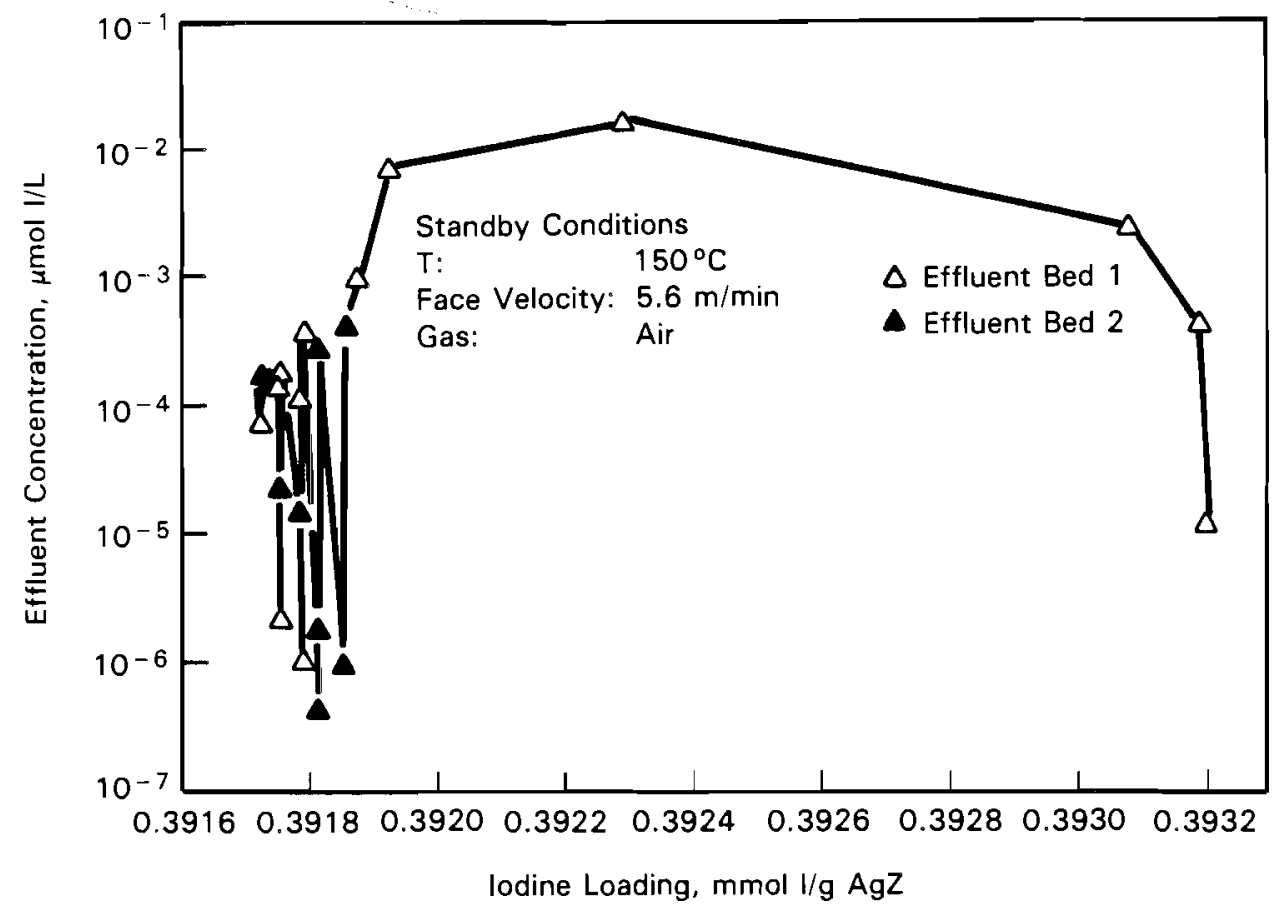

FIGURE 23. Effluent Concentration During Standby Operations for Run 20 (Test of Bed Length and Extended Standby)

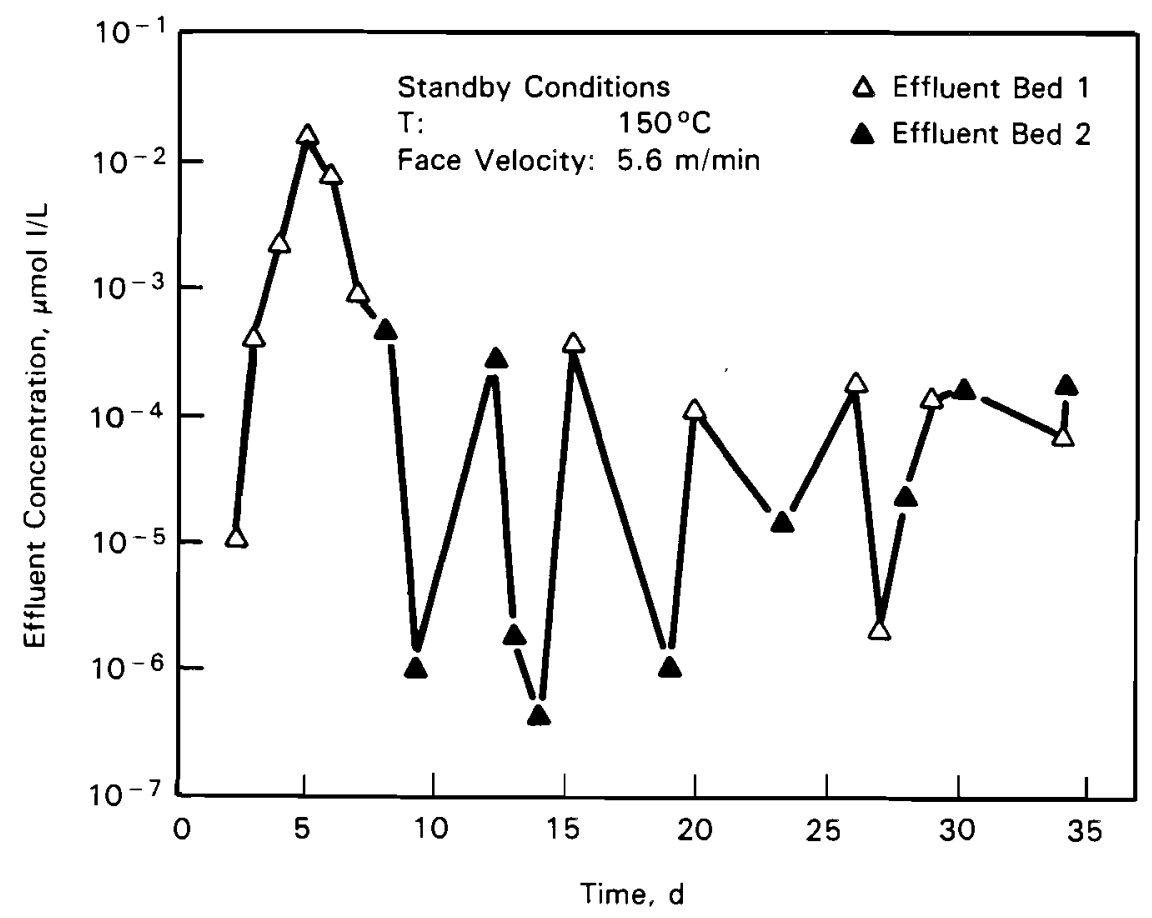

FIGURE 24. Effluent Concentration Versus Time for Run 20 Standby Operations (Test of Bed Length and Extended Standby) 
effluent was typically $10^{-5} \mu \mathrm{mol} \mathrm{I} / \mathrm{L}$, and the standby averaged $2 \times 10^{-6} \mu \mathrm{mol}$ I/L. One loading effluent concentration was quite high and inconsistent with the other effluent concentrations. It was not used to calculate the average effluent concentration before breakthrough reported in Table 4 .

After lodine loading was stopped in run 20 , the standby concentration rose rapidly to $10^{-2} \mu \mathrm{mol} \mathrm{I} / \mathrm{L}$ and remained in the $10^{-3}$ to $10^{-2} \mu \mathrm{mol} \mathrm{I} / \mathrm{L}$ range, as can be seen in Figures 23 and 24 . Thus our hypothes is that iodine loaded onto $\mathrm{AgZ}$ to $0.4 \mathrm{mmol} \mathrm{I} / \mathrm{g}$ would be stable was not verified. It may be that a longer loading time or a higher bed temperature is required to stabilize the iodine on the bed.

The second $16-\mathrm{cm}$ bed, downstream of the loaded first bed, initially reduced the effluent concentration to $10^{-4} \mu \mathrm{mol} I / L$. For the next 8 to 10 days, the effluent concentration from the second bed was typically lower than $10^{-5} \mu \mathrm{mol} \mathrm{I} / \mathrm{L}$ with the exception of one sample. When measured, the effluent from the first bed was $10^{-4} \mu \mathrm{mol} \mathrm{I} / \mathrm{L}$. After another week, the effluent concentration from both beds appeared to level out at about $10^{-4} \mu \mathrm{mol} \mathrm{I} / \mathrm{L}$. This latter result suggests that the lowest achievable effluent concentration during long-term loading will be $10^{-4} \mu \mathrm{mol} \mathrm{I} / \mathrm{L}$ independent of bed length up to $32 \mathrm{~cm}$. It should be noted that the chemical species of the iodine released from the first bed during standby is unknown; however, we belleve that it is probably $\mathrm{I}_{2}$.

Experiment 19, though accidentally run using a $14-\mathrm{cm}$ bed instead of a 12-cm bed, provides supplementary information on the effect of increasing bed length. In this run the $14-\mathrm{cm}$ bed was loaded to $0.5 \mathrm{mmol} \mathrm{I} / \mathrm{g} \mathrm{AgZ}$ before breakthrough, which occurred during standby operation. The effluent concentrations during loading and during standby before breakthrough were $10^{-4}$ and $5 \times 10^{-5} \mu \mathrm{mol} \mathrm{I} / \mathrm{L}$, respectively. The effluent concentrations as a function of the bed loading are presented in Figure 25 . Table 5 compares the results of this experiment with those of experiments 9, 16, 17, and 20 .

Table 5 shows that increasing the bed length increases the iodine loading by a nominal $0.1 \mathrm{mmol} \mathrm{I} / \mathrm{g} \mathrm{AgZ}$ per $2 \mathrm{~cm}$ over $12 \mathrm{~cm}$. The effluent concentration during short-term loading before breakthrough seems to decrease with increasing bed length, although the trend is not consistent. Additional 


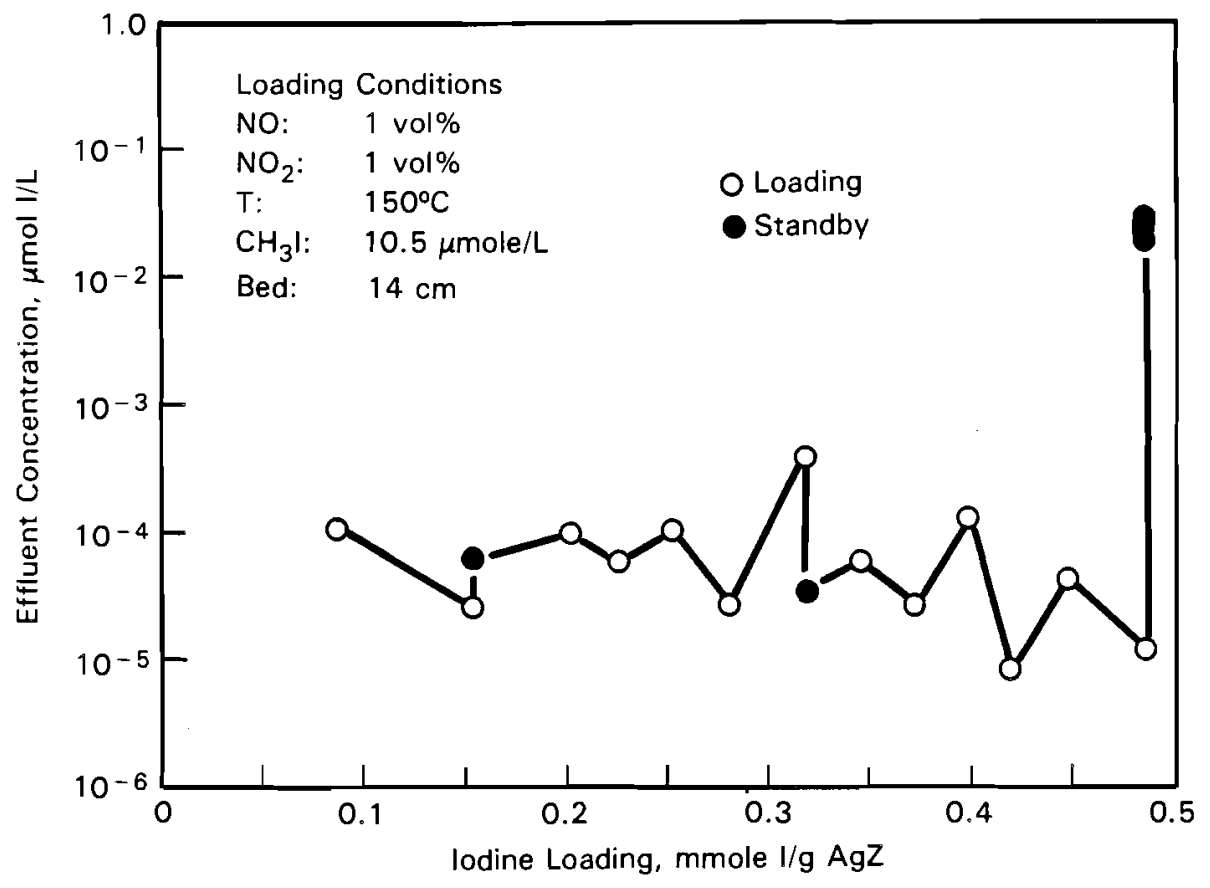

FIGURE 25. Effluent Concentration Versus Iodine Loading on AgZ for Run 19 (Test of Bed Length)

TABLE 5. Summary of Bed Length Test Results

Time-Based

Loading

Bed Length, at Breakthrough, Before Breakthrough,

Run

9

16

19

17

20 $\mathrm{cm}$

12

12

14

16

16 mmol $\mathrm{I} / \mathrm{g} \mathrm{AqZ}$

0.39

0.41

0.49

0.62

ND $\mu \mathrm{mol} \mathrm{I} / \mathrm{L}$

$$
\text { 6.4E-04 }
$$

3. $3 \mathrm{E}-05$

8. $5 \mathrm{E}-05$

8.6E-06

1. $4 \mathrm{E}-05(\mathrm{a})$
Average

Standby Effluent Before Breakthrough, umol I/L

$6.0 \mathrm{E}-06$

9.2E-07

4. $9 \mathrm{E}-05$

8.6E-07

2.3E-06

ND $=$ Not determined .

(a) Does not include second sample of first day; inconsistent with other samples.

studies would be required to determine the effect of bed length on the effluent concentration during loading at the iodine concentrations expected in the PFM. Standby concentrations do not appear to be affected by bed length. 
In summary, these tests show that increasing the bed length will improve the achievable iodine loading on AgZ and may reduce the effluent concentration during loading. The extended standby tests indicate that a portion of the iodine loaded onto AgZ is not firmly fixed and will be removed during standby operations. The rate at which the iodine leaves the bed decreases with time, suggesting that with time the stability of the iodine increases and the iodine becomes less mobile. There is also some indication that the loading level before standby will affect the final stable loading.

\section{TEST OF REDUCED SILVER MORDENITE}

One alternative material which has received some attention as a trapping agent for gaseous radioiodine is hydrogen-reduced silver mordenite $\left(\mathrm{Ag}^{\circ} \mathrm{Z}\right)$, AgZ that has been treated with hydrogen at an elevated temperature to convert most if not all of the ionic silver in the AgZ to metallic silver. $\mathrm{Ag}^{\circ} \mathrm{Z}$ retains many of the attractive characteristics of its parent, such as its chemical stability in acidic systems, and offers potential improvements in loading capacity and stability of the trapped iodine. We chose to test $\mathrm{Ag}^{\circ} \mathrm{Z}$ $(-10+16$ mesh) at normal conditions because a $12-\mathrm{cm}$ bed of $\mathrm{AgZ}$ did not routinely reduce the iodine concentration in the gas to $\left\langle 10^{-5} \mu \mathrm{mol} I / L\right.$.

Trapping of gaseous iodine by $\mathrm{Ag}^{\circ} \mathrm{Z}$ was first studied by Thomas and coworkers (1977) at the Idaho National Engineering Laboratory (INEL). In succeeding studies at $P N L$, we showed that $\mathrm{Ag}^{0} Z$ was somewhat more effective in trapping elemental iodine and methyl iodide than AgZ (Scheele, Burger and Matsuzaki 1983). In PNL's studies the $\mathrm{Ag}^{\circ} \mathrm{Z}$ was superior to $\mathrm{AgZ}$ in terms of iodine loading level at a breakthrough defined as reduction of the gaseous iodine concentration from 13 to $0.13 \mu \mathrm{mol} \mathrm{I} / \mathrm{L}$.

It was our original belief that because of the relatively small quantities of iodine in the fuel to be processed at the PFM, the increased loading level that could be achieved using $\mathrm{Ag}^{\circ} \mathrm{Z}$ was not worth the additional effort and hazard involved with hydrogen reduction. At that time, no studies had been performed to determine whether any iodine trapping material could achieve the PFM target release level for iodine, $\left\langle 10^{-5} \mu \mathrm{mol} \mathrm{I} / \mathrm{L}\right.$. 
As Figure 26 and Table 6 show, breakthrough occurred at a loading of $0.29 \mathrm{mmol} \mathrm{I/g} \mathrm{Ag}{ }^{0} \mathrm{Z}$. Loading was continued to a time-based loading of $0.38 \mathrm{mmol} \mathrm{I/g} \mathrm{Ag}{ }^{0} \mathrm{Z}$. The effluent concentration during loading after breakthrough slowly rose to $5 \times 10^{-3} \mu \mathrm{mol} \mathrm{I} / \mathrm{L}$ at the end of the second day. Sample S-2, the standby sample immediately following this rise, and Sample S-3, which followed the short feed period on the third day, showed high concentrations. The remaining standby samples, including $\mathrm{S}-1$, showed concentrations of $\leq 10^{-5} \mu \mathrm{mol} \mathrm{I} / \mathrm{L}$. Several of the effluent samples were $<0$, as shown in Table 6 . These samples were arbitrarily assigned effluent concentrations of $10^{-5} \mu \mathrm{mol} \mathrm{I} / \mathrm{L}$ for plotting purposes in Figure 26. Unfortunately this experiment was performed when the ${ }^{125}$ I had aged several halflives, causing an increase in the detection limit. Because of this problem, the apparent results need to be confirmed.

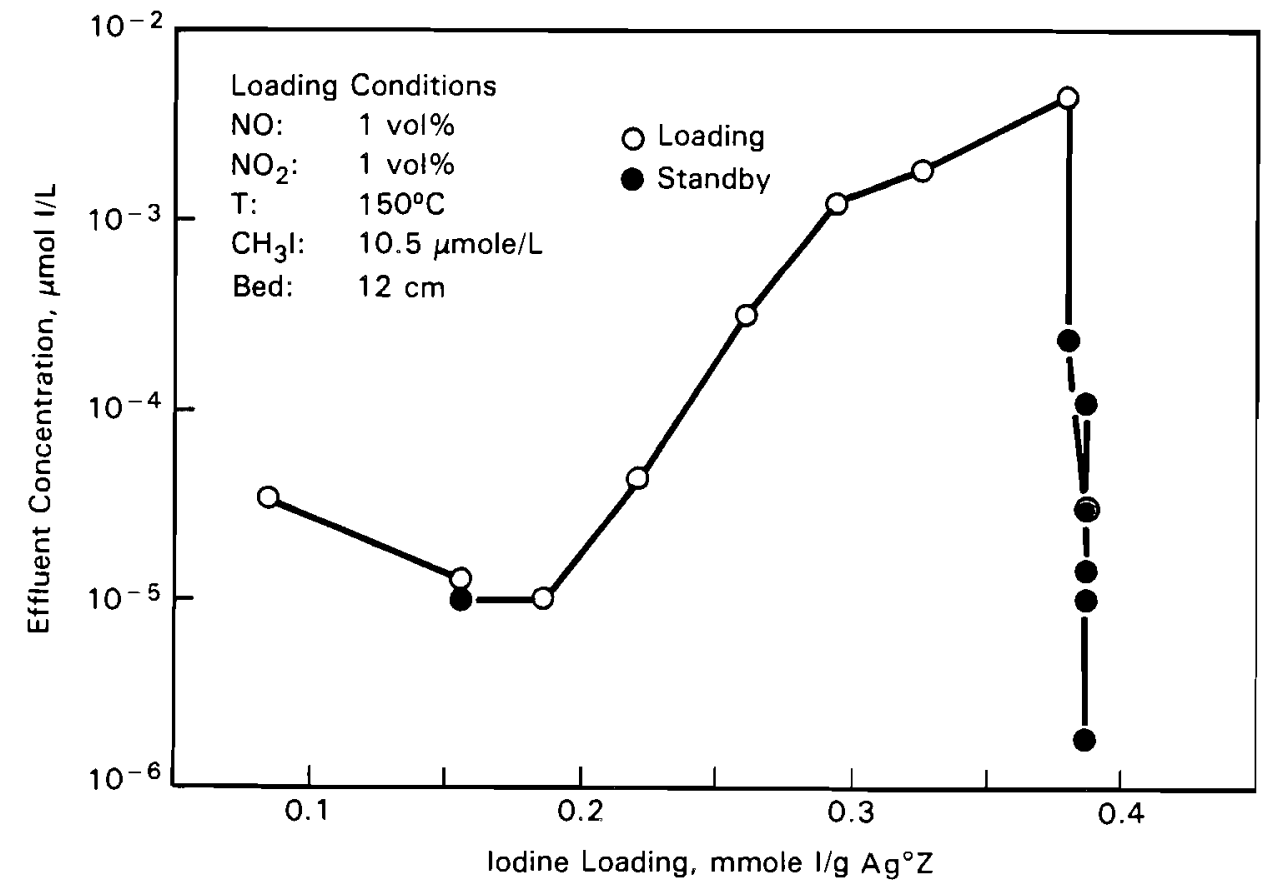

FIGURE 26. Effluent Concentration Versus Iodine Loading on $\mathrm{Ag}^{\circ} \mathrm{Z}$ for Run 22 (Test of $\mathrm{Ag} \mathrm{Z}$ ) 
TABLE 6. Iodine Trapping by $\mathrm{Ag}^{\circ} \mathrm{Z}$ in Run 22

\begin{tabular}{|c|c|c|c|c|}
\hline \multirow[b]{2}{*}{ Day No. } & \multirow{2}{*}{$\begin{array}{c}\text { Elapsed Time } \\
\text { hrs }\end{array}$} & \multirow{2}{*}{$\begin{array}{l}\text { Sample } \\
\text { No. }\end{array}$} & \multicolumn{2}{|c|}{$\begin{array}{l}\text { Effluent Concentration } \\
\mu \mathrm{mol} \mathrm{I} / \mathrm{L}\end{array}$} \\
\hline & & & Loading & Standby \\
\hline \multirow[t]{3}{*}{1} & 3 & $E-1$ & $3.4-05$ & - \\
\hline & 6 & $E-2$ & $1.3-05$ & - \\
\hline & 22 & $S-1$ & - & $<0$ \\
\hline \multirow[t]{7}{*}{2} & 23 & $E-3$ & $1.0-05$ & - \\
\hline & & $E-4$ & 4.4-05 & - \\
\hline & & $E-5$ & $3.1-04$ & - \\
\hline & & $E-6$ & $1.3-03$ & - \\
\hline & & $E-7$ & $1.9-03$ & - \\
\hline & 29 & $E-8$ & $4.7-03$ & - \\
\hline & 46 & $s-2$ & - & 2.4-04 \\
\hline \multirow[t]{3}{*}{3} & 47 & $E-9$ & $3.0-05$ & \\
\hline & 50 & $S-3$ & - & $1.1-04$ \\
\hline & 53 & $S-4$ & - & $<0$ \\
\hline \multirow[t]{2}{*}{4} & 70 & $S-5$ & - & $3.1-05$ \\
\hline & 77 & $S-6$ & - & $<0$ \\
\hline \multirow[t]{2}{*}{5} & 119 & $S-7$ & - & $1.4-05$ \\
\hline & 125 & $S-8$ & - & $<0$ \\
\hline 8 & 190 & $S-9$ & - & $2.0-06$ \\
\hline 9 & 216 & S-10 & - & $<0$ \\
\hline
\end{tabular}

The loading at breakthrough for $\mathrm{Ag}^{\circ} \mathrm{Z}$ was $30 \%$ less than that achieved for run 9, which tested AgZ at comparable conditions. This result was surprising because of our past work (Scheele, Burger, and Matsuzaki 1983), which showed that higher loadings could be obtained using $\mathrm{Ag}^{\circ} \mathrm{Z}$. It is unknown whether application of the same criteria for breakthrough used in the current study would affect the previously obtained results.

From this experiment, it also appears that the iodine trapped on $\mathrm{Ag}^{\mathrm{O}} \mathrm{Z}$ at 0.4 mimol $\mathrm{I} / \mathrm{g} \mathrm{Ag}^{0} \mathrm{Z}$ is less mobile than iodine trapped on $\mathrm{AgZ}$ at a comparable 
loading. After a few days of standby operation, the chronic release from this $12-\mathrm{cm}$ bed of $\mathrm{Ag}^{0} \mathrm{Z}$ was near the target concentration. In contrast, the chronic release from the $16-\mathrm{cm}$ bed of $\mathrm{AgZ}$ loaded to $0.4 \mathrm{mmol} \mathrm{I} / \mathrm{g} \mathrm{AgZ}$ (experiment 20, Figures 23 and 24) decreased to and stabilized at $10^{-4} \mu \mathrm{mol}$ $I / L$ after 20 days. The results of this single test suggest with $\mathrm{Ag}^{\circ} \mathrm{Z}$ that it may be possible to achieve a higher loading and still have a stable trapped iodine. Further experimentation is required before the utility of $\mathrm{Ag}^{\circ} \mathrm{Z}$ can be fully assessed for application at the PFM. 



\section{CONCLUSIONS}

With some qualifications, silver mordenite (AgZ) is an effective trap for iodine, capable of reducing the effluent iodine concentration in the PFM dissolver off gas to a nominal $10^{-4} \mu \mathrm{mol} \mathrm{I} / \mathrm{L}$. Although this concentration is about a factor of 10 greater than the target level for the PFM, there are reasons to believe that the larger zeolite bed to be used in the PFM and the longer time for reaction may improve the efficiency even more.

If a nearly loaded AgZ bed is exposed to a gas stream without iodine present, a breakthrough can occur during these standby conditions. Indications are that the bed will stabilize after an extended period at a loading of $0.4 \mu \mathrm{mol} / \mathrm{g} \mathrm{AgZ}$. At PFM a backup adsorber bed will be provided to prevent unacceptable releases after breakthrough of the first bed. The data indicate that the backup bed will be effective for this purpose.

The statistical analysis of the parametric study to determine the effect of normal and off-normal operating conditions showed that there is no NO or $\mathrm{NO}_{2}$ effect and only a small negative, though statistically significant, temperature effect when temperature is increased from 150 to $230^{\circ} \mathrm{C}$. These experiments showed that on a practical basis the loading is not significantly $(>10 \%)$ affected by changes in operating conditions.

The special tests produced several significant findings. The first is that a longer bed will improve the short-term load capacity of the AgZ and, before breakthrough, will reduce the effluent concentration to the target level during loading at normal and standby conditions. Secondly, the iodine input level in the range 0.35 to $10.5 \mu \mathrm{mol} \mathrm{CH}_{3} \mathrm{I} / \mathrm{L}$ will not affect the effluent concentration or the bed loading at normal conditions. Thirdly, a second bed in series will initially reduce the effluent concentration from an off-gas system to the desired level (i.e., equivalent to a longer bed); however, over time the effluent will increase to the nominal $10^{-4} \mu \mathrm{mol} \mathrm{I} / \mathrm{L}$. Finally, on the basis of the breakthrough criteria of this study, the achievable iodine loading on $\mathrm{Ag}^{0} \mathrm{Z}$ is $0.3 \mathrm{mmol} \mathrm{I} / \mathrm{g} \mathrm{Ag}^{\circ} \mathrm{Z}$, which is $30 \%$ less than the loading for AgZ loaded at comparable conditions. The iodine loaded on $\mathrm{Ag}^{\circ} \mathrm{Z}$, however, appears to be less mobile than that loaded onto AgZ. 
This experimental program showed that even though AgZ was effective as an iodine trap at all potential conditions in the PFM, the performance of a $12-\mathrm{cm}$ bed did not meet all of the target criteria. Before it is possible to ensure that the target control levels of the PFM will be met, additional studies may be required. These studies might include a long-term test using the expected PFM iodine concentration and PFM bed length, comparison of alternative materials and studies to understand and control the chemistry and reaction rates of the trapping process. 
RECOMMENDED FUTURE WORK

In light of the results showing higher-than-targeted iodine effluent concentrations and poor retention of iodine at standby conditions, we recommend an experimental program to include a screening study of other state-of-the-art silver sorbents and a fundamental study to determine the mechanism of iodine trapping and a method to reduce the mobility of trapped iodine during standby operations. Further special tests, such as an extended loading experiment using the process iodine concentration and a long bed $(>12$ $\mathrm{cm}$ ) to confirm the results of the long-bed tests, are also suggested.

A fundamental study could use thermoanalytical techniques such as differential scanning calorimetry (DSC) and thermogravimetry (TG) to measure enthalpy and rate of the sorption reaction. The DSC and TG techniques could also be used to determine the stability of sorbed iodine on silver sorbents. other studies could use surface analysis or spectroscopic techniques to analyze iodine-loaded materials.

The screening study to determine which of the current state-of-the-art silver-containing sorbents would be most effective under the conditions of PFM operation could be approached in many different ways. Experiments such as those already completed could be performed to allow comparison with AgZ. If one of the materials offers promise, a more extensive set of experiments could be performed similar to the parametric study described in this report. Alternatively, or in addition, shallow beds of silver sorbent could be used to determine the kinetics of the sorption reaction. No kinetic data are currently available; the shallow-bed tests could also be considered the fundamental studies. These kinetic studies should all be done using all of the individually suspected iodine forms in a dissolver off gas.

As can be seen from the above list of suggested studies (this list is by no means comprehensive), there is much to be learned about the trapping of iodine from a dissolver off-gas strean. Previous studies have concentrated on the empirical demonstration of the process and have not looked at the basic mechanism of trapping. Nor have earlier studies attempted to determine the limits of use for each state-of-the-art silver sorbent. 

REFERENCES

Burger, L. L., and R. D. Scheele. 1982a. Recycle of Iodine-Loaded Silver Mordenite by Hydrogen Reduction. PNL-4490, Pacific Northwest Laboratory, Richland, Washington.

Burger, L. L., and R. D. Scheele. 1982b. "Iodine Fixation Studies at the Pacific Northwest Laboratory," in Management Modes for Iodine 129,

W. Hebel and G. Cottone, eds. Harwood Academic Publishers, New York.

Scheele, R. D., L. L. Burger, and C. L. Matsuzaki. 1983. Methyl Iodide Sorption by Reduced Silver Mordenite. PNL-4489, Pacific Northwest Laboratory, Richland, Washington.

Thomas, T. R., L. P. Murphy, B. A. Staples, and J. T. Nichols. 1977. Airborne Elemental Iodine Loading Capacities of Metal Zeolites and A Method for Recycling Silver Zeolite. ICP-1119, Idaho National Engineering Laboratory, Idaho Falls, Idaho.

Venuto, P. B., and P. S. Landis. 1968. "Organic Catalys is Over Crystalline Aluminosilicates." In Advances in Catalysis and Related Subjects Vol. 18. Ed. D. D. Eley, H. Pines, and P. B. Weisz. Academic Press, New York.

Yost, D. M., and H. R. Russel1, Jr. 1944. Systematic Inorganic Chemistry of the 5th and 6th Group Non-Metall ic Element. Prentice-Hall Inc., New York. 

APPENDIX A

PREVIOUS AgZ - METHYL IODIDE TESTS 



\section{PREVIOUS AgZ - METHYL IODIDE TESTS}

In the preliminary iodine-trapping experiments carried out for the PFM Project $^{(a)}$, several tests were performed to demonstrate the effectiveness of $\mathrm{AgZ}$ as a trap for $\mathrm{CH}_{3} \mathrm{I}$. At the time, the PFM plan was to use a caustic scrub to remove the bulk of the $\mathrm{I}_{2}$, which was estimated to be more than $90 \%$ of the total iodine, and to use $\mathrm{AgZ}$ to capture the remaining $\mathrm{I}_{2}$ and the organic iodides.

The first tests performed in conjunction with the caustic scrubbing experiments showed that a $5-\mathrm{cm}$-diameter by $15-\mathrm{cm}-$ long bed at $150^{\circ} \mathrm{C}$ could reduce the gas phase concentration of $\mathrm{CH}_{3} \mathrm{I}$ from $2.5,14$, and $25 \mu \mathrm{mol} \mathrm{I} / \mathrm{L}$ by a retention factor (RF) of $>10^{3}$. The last test was to demonstrate that an $\mathrm{AgZ}$ bed could reduce the effluent concentration to $\left\langle 10^{-3} \mu \mathrm{mol} \mathrm{I} / \mathrm{L}\right.$.

The objective of this single experiment was to determine the efficiency for $\mathrm{CH}_{3} \mathrm{I}$ capture and the loading capacity at the target effluent concentration of $10^{-3} \mu \mathrm{mol} \mathrm{I} / \mathrm{L}$. The experimental parameters are shown in Table A.1. The bed had sampling ports at $3,8,13$, and $18 \mathrm{~cm}$ from the top (inlet) of the $\mathrm{AgZ}$ bed. The $\mathrm{CH}_{3} \mathrm{I}$ was traced with ${ }^{125} \mathrm{I}$. We measured the iodine concentration in the effluent by passing a $100 \mathrm{~mL} / \mathrm{min}$ sample stream through a $1.3-\mathrm{cm}-\mathrm{diameter}$ by $11-\mathrm{cm}-$ long bed of 20 to 40 mesh $\mathrm{AgZ}$ held at $200^{\circ} \mathrm{C}$ to collect the radioiodine. The radioiodine was then measured with a $\mathrm{NaI}$ (TI) scintillation garrma detector.

At the end of each day of loading, the side ports were sealed, the temperature was lowered to ambient, $\sim 23^{\circ} \mathrm{C}$, and the air flow adjusted to $0.5 \mathrm{~L} / \mathrm{min}(0.25 \mathrm{~m} / \mathrm{min}$ face velocity). Charcoal traps were placed at the bed exit during this standby operation to detect possible leakage of the iodine. A small amount, $\sim 10^{-6}$ fraction, was found. The bed temperature was raised to $150^{\circ} \mathrm{C} 1.5$ hours before the next loading began.

(a) Letter report to Rockwell by L. L. Burger, R. D. Scheele, and C. L. Matsuzaki. 1983. PFM Iodine Removal Studies, Pacific Northwest Laboratory, Richland, Washington. 
TABLE A.1. Operational Parameters for $\mathrm{CH}_{3} \mathrm{I}-\mathrm{AgZ}$ Experiment

\begin{tabular}{|c|c|}
\hline Parameters & Level \\
\hline $\mathrm{I}_{2}$ concentration, $\mu \mathrm{mol} \mathrm{I} / \mathrm{L}$ & 0 \\
\hline $\mathrm{CH}_{3} \mathrm{I}$ concentration, $\mu \mathrm{mol} \mathrm{I} / \mathrm{L}$ & 10 \\
\hline $\mathrm{NO}_{x}$ concentration, vol \% & 0.5 \\
\hline NO concentration, vol\% & 0.38 \\
\hline $\mathrm{NO}_{2}$ concentration, vol\% & 0.12 \\
\hline Carrier gas & Laboratory air ${ }^{(a)}$ \\
\hline Gas Flow, L/min & 10 \\
\hline Gas Face velocity, $\mathrm{m} / \mathrm{min}$ & 5 \\
\hline AgZ column diameter, cm & 5.0 \\
\hline Agz column height, $\mathrm{cm}$ & 18.0 \\
\hline Packing & $\begin{array}{l}14-20 \text { mesh } \mathrm{AgZ} \text {, } \\
18 \mathrm{wt} \% \mathrm{Ag}\end{array}$ \\
\hline Agz bed temperature, ${ }^{\circ} \mathrm{C}$ & 150 \\
\hline Bed Mass & $\sim 300 \mathrm{~g}$ \\
\hline
\end{tabular}

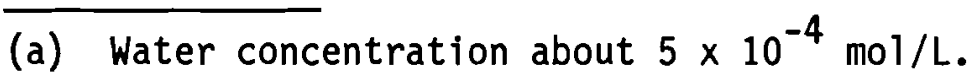

The results of the test are shown in Figure A.1 which shows the effluent concentration as a function of bed loading. If the momentary spikes evident from the 8-, 13- and 18-cm sample ports are ignored, the loading at a breakthrough concentration of $1 \times 10^{-3} \mu \mathrm{mol} \mathrm{I} / \mathrm{L}$ can be compared. These are shown in Table A.2.

TABLE A.2. Bed Loading at Breakthrough

\begin{tabular}{cc}
$\begin{array}{c}\text { Bed Depth, } \\
\mathrm{cm}\end{array}$ & $\frac{\text { Bed Loading at } 1.0 \times 10^{-3} \mu \mathrm{mol}}{\text { Breakthrough }(\mathrm{mmol} \mathrm{I} / \mathrm{g} \mathrm{AgZ})}$ \\
\hline 3 & 0.06 \\
8 & 0.31 \\
13 & 0.61 \\
18 & 0.97
\end{tabular}


Recognizing that the higher concentration spikes seen in Figure A.1 may be significant, a more conservative loading may be identified. For the 13- and $18-\mathrm{cm}$ beds this would be about 0.5 and $0.75 \mathrm{mmol} \mathrm{I} / \mathrm{g} \mathrm{AgZ}$ respectively.

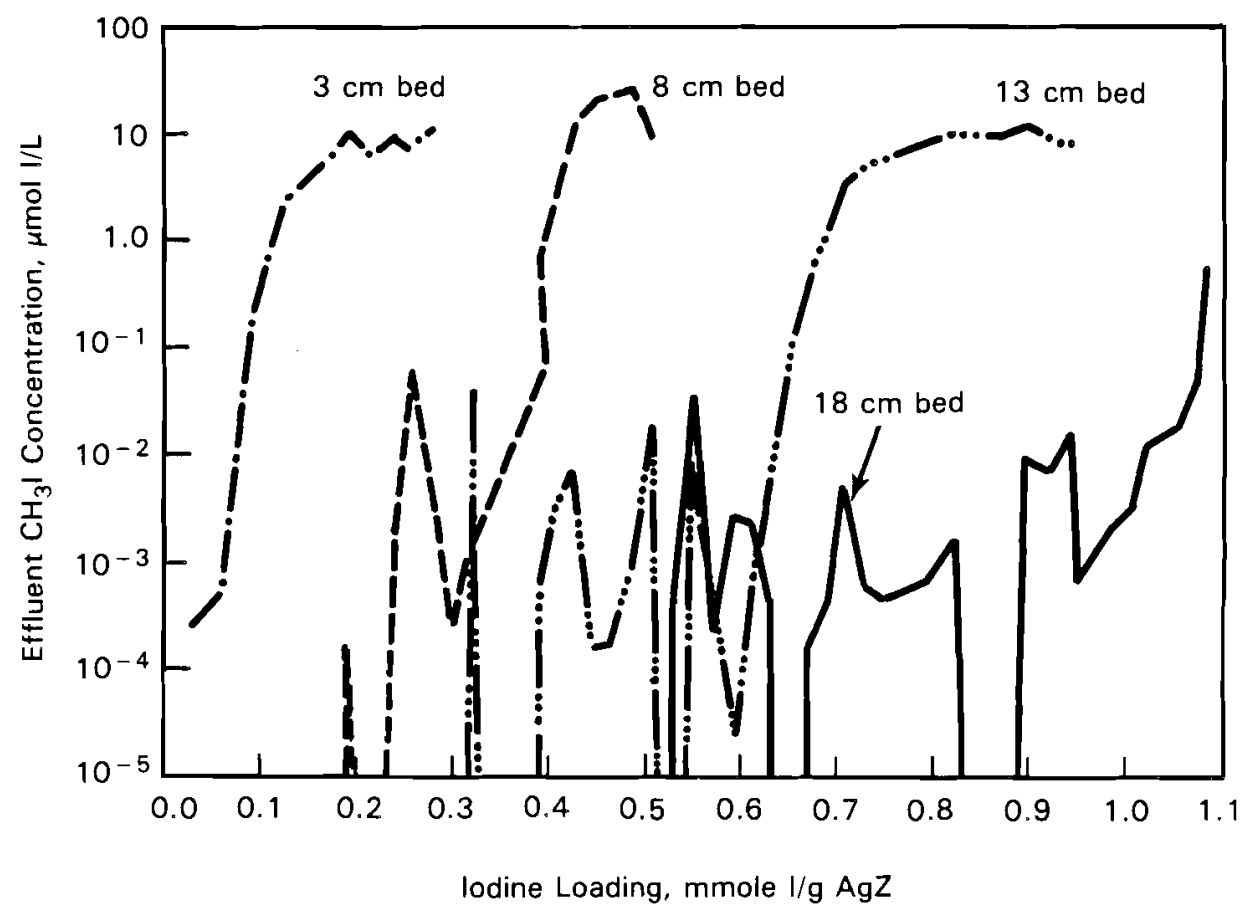

FIGURE A.1. Effluent Concentration Versus Iodine Loading for 18-cm Bed of AgZ (Previous Work) 
APPENDIX B

AgZ DENSITY AND PRESSURE DROP MEASUREMENTS 



\section{$\underline{\text { APPENDIX B }}$}

\section{AgZ DENSITY AND PRESSURE DROP MEASUREMENTS}

\section{ZEOLITE DENSITY}

Three batches of AgZ ranging in silver content from 18.76 to $19.08 \mathrm{wt} \%$ were combined. The $-10+16$ mesh material showed density variation from 0.985 to $1.02 \mathrm{~g} / \mathrm{mL}$. The variation was probably due to slight differences in size distribution and hence packing. The free volume was about $40 \%$. The composite density after air equilibration was 0.993 . The water content, as indicated by drying at $450^{\circ} \mathrm{C}$, was about $10 \%$.

\section{PRESSURE DROP STUDIES}

The pressure drop through AgZ beds of different mesh sizes was measured with nitrogen gas at flow rates from 1.7 to $17 \mathrm{~m} / \mathrm{min}$ face velocity, and at 22, 100 , and $200^{\circ} \mathrm{C}$. The data are given in Tables B.1 and B.2. The pressure drop will depend on the particle size distribution within a mesh range and upon the degree of settling reached in preparing the bed samples. The measured densities of the samples represented in Table B.1, for example, varied by $\pm 5 \%$. It would not be surprising to have pressure drops vary from $10 \%$ to $20 \%$ for different batches of as-received zeolite of a given mesh range.

The pressure drop increases rapidly as the mesh decreases. For a flow of $600 \mathrm{~mL} / \mathrm{min}(4.9 \mathrm{~m} / \mathrm{min}$ face velocity), the pressure drop for the $1.25-\mathrm{cm}-\mathrm{di}$ ameter bed at $22^{\circ} \mathrm{C}$ is about $90,165,470,790$, and $2210 \mathrm{~mm} \mathrm{H} \mathrm{H}_{2} \mathrm{O}$ per meter of bed length for $-10+16,-14+20,-20+30,-30+40$, and $-40+70$ mesh, respectively. The pressure drop increase from room temperature to $100^{\circ} \mathrm{C}$ is 40 to $50 \%$ and from 100 to $200^{\circ} \mathrm{C}$ is $30 \%$. For the experimental arrangement used in the iodine sorption tests, the observed pressure drop in the bed and connecting tubing was about 16 to $20 \mathrm{~mm} \mathrm{H}_{2} \mathrm{O}$. 
TABLE B.1. Pressure Drop in AgZ Beds (a)

\begin{tabular}{|c|c|c|c|c|}
\hline \multirow{2}{*}{$\begin{array}{l}\mathrm{Flow}, \\
\mathrm{mL} / \mathrm{min}\end{array}$} & \multicolumn{4}{|c|}{ 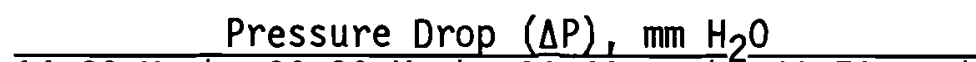 } \\
\hline & 14-20 Mesh & $20-30$ Mesh & $30-40 \mathrm{Mesh}^{2}$ & 40-70 Mesh \\
\hline 200 & 52 & 141 & 237 & 756 \\
\hline 400 & 89 & 274 & 474 & 1410 \\
\hline 500 & 126 & -- & -- & -- \\
\hline 600 & 163 & 467 & 785 & 2210 \\
\hline 700 & -- & -- & -- & 2610 \\
\hline 800 & 237 & 637 & 1030 & -- \\
\hline 1000 & 333 & 844 & 1330 & -- \\
\hline 1200 & 444 & 1090 & 1710 & -- \\
\hline 1400 & 533 & 1330 & 2020 & -- \\
\hline 1600 & 600 & 1470 & 2230 & -- \\
\hline 1800 & 652 & 1560 & 2380 & -- \\
\hline 2000 & 770 & 1900 & 2760 & -- \\
\hline
\end{tabular}

Coefficients for
Equation $\Delta P=A$ (Flow)

$\begin{array}{lllll}\text { A } & 0.0597 & 0.304 & 0.770 & 3.95 \\ \text { B } & 1.245 & 1.148 & 1.080 & 0.988 \\ R^{2} & 0.991 & 0.997 & 0.999 & 0.997\end{array}$

(a) Dia. $1.25 \mathrm{~cm}$, temp. $23^{\circ} \mathrm{C}$. 
TABLE B.2. Temperature Dependence of Pressure Drop (a)

\begin{tabular}{|c|c|c|c|c|}
\hline \multirow{2}{*}{$\begin{array}{l}\text { Flow, } \\
\mathrm{mL} / \mathrm{min}\end{array}$} & \multirow{2}{*}{$\begin{array}{l}\text { Face Velocity, } \\
\mathrm{m} / \mathrm{min}\end{array}$} & \multicolumn{3}{|c|}{ Pressure Drop $(\Delta P)$, } \\
\hline & & at 220 & at 1000 & at $200^{\circ} \mathrm{C}$ \\
\hline 300 & 2.44 & -- & 58 & 95 \\
\hline 325 & 2.64 & 44 & -- & -- \\
\hline 600 & 4.88 & 90 & -- & -- \\
\hline 800 & 6.50 & 128 & 191 & 251 \\
\hline 1000 & 8.15 & 169 & 245 & 345 \\
\hline 1500 & 12.2 & -- & 410 & 567 \\
\hline 2000 & 16.3 & 442 & 617 & 803 \\
\hline
\end{tabular}

(a) Dia. $1.25 \mathrm{~cm}$, mesh $-10+16$, length $12.7 \mathrm{~cm}$, gas $\mathrm{N}_{2}$.

(b) Measured at $23^{\circ} \mathrm{C}$. 


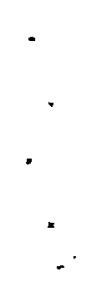




\section{DISTRIBUTION}

No. of

Copies

OFFSITE

R. A. Brown

Exxon Nuclear Idaho

P.0. Box 2800

Idaho Falls, ID 83401

J. D. Christian

Exxon Nuclear Idaho

P.0. Box 2800

Idaho Falls, ID 83401

R. T. Jubin

Oak Ridge National Laboratory

P.0. Box $X$

Oak Ridge, TN 37830

T. R. Thomas

Exxon Nuclear Idaho

P.0. Box 2800

Idaho Falls, ID 83401

30 DOE Technical Information Center

\section{FOREIGN}

J. Furrer

Karlsruhe Nuclear Center

7500 Karlsruhe

Federal Republic of Germany

D. F. Torgerson

Whiteshel1 Nuclear Research

Establishment

Atomic Energy of Canada

Pinawa, Manitoba, Canada
No. of

Copies

ONSITE

DOE-Richland Operations

J.D. Furubotten (2)

J.J. Sutey

Hanford Engineering

Development Laboratory

R. E. Lerch

22 Rockwel1 Hanford Operations

D. E. Ball

G. L. Borsheim

D. R. Bratzel

C. R. Cawley

G. E. Coulter

D. A. Dodd

E. W. Harris

D. L. Herting

J. P. Hinckley

K. N. Jordan

E. J. Kosiancic

W. F. Nicaise

R. M. Orme

K. E. Plummer

G. W. Reddick

D. A. Reynolds

R. C. Roal

D. E. Scully

W. W. Schulz

J. A. Swenson

D. J. Washenfelder

E. D. Waters 
No. of

Copies

39 Pacific Northwest Laboratory

W. F. Bonner

D. J. Bradley

F. P. Brauer

L. A. Bray

L. L. Burger (2)

D. G. Coles

R. W. Goles

E. J. Kaiser

R. S. Kemper

L. T. Lakey

J. W. Latkovich

S. F. Liebetrau

J. L. McElroy

A. M. Platt

W. A. Ross

L. J. Sealock

R. D. Scheele (10)

J. K. Soldat

J. L. Straalsund

J. L. Swanson

P. C. Walkup

E. J. Wheelwright

Publishing Coordination (2)

Technical Report Files (5) 